\title{
Comparative Analysis of the Apple Root Transcriptome as Affected by Rootstock Genotype and Brassicaceae Seed Meal Soil Amendment: Implications for Plant Health
}

\author{
Likun Wang $^{1,+}$, Tracey S. Somera ${ }^{2,+}$, Heidi Hargarten ${ }^{2} \mathbb{D}$, Loren Honaas ${ }^{2}$ and Mark Mazzola ${ }^{2,3, *}$ \\ 1 Department of Plant Pathology, Washington State University, Pullman, WA 99164, USA; likun.wang@wsu.edu \\ 2 USDA-ARS Tree Fruit Research Lab, 1104 N. Western Ave, Wenatchee, WA 98801, USA; \\ tracey.somera@usda.gov (T.S.S.); heidi.hargarten@usda.gov (H.H.); loren.honaas@usda.gov (L.H.) \\ 3 Department of Plant Pathology, Stellenbosch University, Matieland 7600, South Africa \\ * Correspondence: mark@resourcesolutionsnow.com; Tel.: +1-509-670-1189 \\ + These authors contributed equally to this work.
}

Citation: Wang, L.; Somera, T.S.; Hargarten, H.; Honaas, L.; Mazzola, M. Comparative Analysis of the Apple Root Transcriptome as Affected by Rootstock Genotype and Brassicaceae Seed Meal Soil

Amendment: Implications for Plant Health. Microorganisms 2021, 9, 763. https://doi.org/10.3390/ microorganisms 9040763

Academic Editor: Christopher B. Blackwood

Received: 21 March 2021

Accepted: 4 April 2021

Published: 6 April 2021

Publisher's Note: MDPI stays neutral with regard to jurisdictional claims in published maps and institutional affiliations.

Copyright: (c) 2021 by the authors. Licensee MDPI, Basel, Switzerland. This article is an open access article distributed under the terms and conditions of the Creative Commons Attribution (CC BY) license (https:// creativecommons.org/licenses/by/ $4.0 /)$.

\begin{abstract}
Brassicaceae seed meal (SM) soil amendment has been utilized as an effective strategy to control the biological complex of organisms, which includes oomycetes, fungi, and parasitic nematodes, that incites the phenomenon termed apple replant disease. Soil-borne disease control attained in response to Brassicaceae SM amendment is reliant on multiple chemical and biological attributes, including specific SM-generated modifications to the soil/rhizosphere microbiome. In this study, we conducted a comparative analyses of apple root gene expression as influenced by rootstock genotype combined with a seed meal (SM) soil amendment. Apple replant disease (ARD) susceptible (M.26) and tolerant (G.210) rootstocks cultivated in SM-amended soil exhibited differential gene expression relative to corresponding non-treated control (NTC) orchard soil. The temporal dynamics of gene expression indicated that the SM-amended soil system altered the trajectory of the root transcriptome in a genotype-specific manner. In both genotypes, the expression of genes related to plant defense and hormone signaling were altered in SM-amended soil, suggesting SMresponsive phytohormone regulation. Altered gene expression was temporally associated with changes in rhizosphere microbiome density and composition in the SM-treated soil. Gene expression analysis across the two rootstocks cultivated in the pathogen-infested NTC soil showed genotypespecific responses indicative of different defensive strategies. These results are consistent with previously described resistance mechanisms of ARD "tolerant" rootstock cultivars and also add to our understanding of the multiple mechanisms by which SM soil amendment and the resulting rhizosphere microbiome affect apple rootstock physiology. Future studies which assess transcriptomic and metagenomic data in parallel will be important for illuminating important connections between specific rhizosphere microbiota, gene-regulation, and plant health.
\end{abstract}

Keywords: apple; transcriptome; soil microbiome; Brassicaceae seed meal; replant disease

\section{Introduction}

Brassicaceae plant residues have been studied extensively for the capacity to control soil-borne plant pathogens and pests when applied as a soil amendment [1]. The preponderance of work has focused on the pesticidal properties of glucosinolate hydrolysis products, particularly isothiocyanates, generated in response to soil incorporation of these plant residues [2-4]. However, multiple complementary and/or concurrent mechanisms of action have been proposed to contribute to disease suppression in response to Brassicaceae seed meal (SM) soil amendments, including generation of ephemeral pesticidal compounds noted above, amplification of microbial elements that directly parasitize pathogens [5], increases in the abundance of microbes producing anti-microbial metabolites, and the potential induction of host defense responses [6]. For example, significant evidence exists 
demonstrating effective disease control of some (but not all) pathogens in response to Brassica napus SM soil amendment irrespective of production of glucosinolate hydrolysis products [7,8]. A functional microbiome of specific composition as modified by the SM amendments can be a key requirement for disease control [5,9].

Numerous studies have documented compositional changes in the soil or rhizosphere microbiome triggered by application of organic soil amendments [10-13]. Root-associated microbes can work as a whole and generate physiological changes in the host plant that result in activation of host defense responses against pathogens [14-18]. Similarly, longterm soil-borne disease suppression following Brassicaceae SM treatment functions, at least in part, through the resident soil microbiome [5,6,8,12]. Specific Brassicaceae seed meal formulations provided long-term suppression of the pathogen complex that incites apple replant disease (ARD), including multi-year control of the root lesion nematode, Pratylenchus penetrans, and Pythium spp. when assessed in field trials [12,19]. Disease suppression is consistently associated with amplification of specific plant beneficial components of the rhizosphere microbiome, including Arthrobotrys spp., Trichoderma spp., Chaetomium spp., Humicola spp., Bacillus spp., and various actinomycetes [9,12,19].

Due to the complexity of plant-soil systems, understanding of the molecular interactions between plant roots and soil-borne pathogens has lagged behind foliar pathosystems [20]. Although mechanisms contributing to disease control in response to Brassicaceae SM soil amendments have been investigated, the molecular mechanisms leading to effects on the plants themselves have not been studied extensively. Cohen et al. [6] demonstrated that apple root infection by Rhizoctonia solani AG-5 was suppressed when cultivated in Brassica napus SM-amended soil. The study indicated that the SM-mediated plant protection may be systemic and was initiated through amplification of certain components of the rhizosphere microbiome, specifically Streptomyces spp. While global gene expression profiling has been reported for plants in response to other soil treatments [21,22], transcriptomic studies which attempt to explore relationships between host gene expression and microbiome composition have primarily been limited to the human gut microbiome.

In addition to assessing transcriptome changes in response to planting apple in SMamended soils, differential gene expression between the apple rootstocks G.210 and M.26 rootstocks was also evaluated in this study for plants established in non-treated control soil in order to explore genotype-dependent mechanisms affecting host tolerance. Previously, elevated transcript abundance in root tissue for many defense response genes, including genes encoding proteins involved in defense hormone signaling, was observed in the ARD tolerant apple rootstock genotype G.935 relative to the susceptible rootstock Bud.9 [23,24] when cultivated in the absence of pathogen pressure. The authors hypothesized that the tolerant genotype was better "primed" to defend against necrotrophic pathogen infection relative to the susceptible genotype. In addition, it is known that the ARD tolerant G.210 rootstock allocates a greater portion of its biomass below ground and maintains higher rates of root growth than the susceptible M.26 rootstock [25]. Therefore, resilience to root loss in G.210 may also play a pivotal role in tolerance to ARD [25,26].

In this study, it was hypothesized that: (i) genes encoding proteins that function in pathogen defense and hormone signaling are induced in response to SM application, (ii) alteration of host gene expression when cultivated in SM-treated soil is associated with changes in the rhizosphere-microbiome, and (iii) ARD-tolerance is associated with rootstock genotype-specific transcriptional changes related to more rapid defense induction, as well as modulation of root architecture.

\section{Materials and Methods}

\subsection{Experimental Design}

Soil used in this study was collected, as previously described, from a commercial orchard (GC) in Manson, WA, USA (N 47 $53^{\prime} 05^{\prime \prime}, \mathrm{W} 120^{\circ} 09^{\prime} 30^{\prime \prime}$ ), possessing the diversity of elements previously shown to comprise the causal apple replant disease pathogen complex $[27,28]$. Seed meals utilized in this study were derived from Brassica juncea cv. 
Pacific Gold [29] and Sinapis alba cv. Ida Gold [30]. SMs were blended at a ratio of 1:1, passed through a $1-\mathrm{mm}^{2}$ pore diameter sieve, and applied at a rate of $20 \mathrm{~g}$ per $2 \mathrm{~kg}$ of soil $\left(=4.4 \mathrm{t} \mathrm{ha}^{-1}\right)$. Soil was transferred into individual 3.8-L pots after treatment and incubated on the greenhouse bench for 6 weeks to allow for degradation of potential herbicidal compounds.

Cloned M.26 and G.210 rootstock plantlets were generated by tissue culture, using previously described methods [31]. Six-week-old plantlets were planted into no treatment control (NTC) and $4.4 \mathrm{t} \mathrm{ha}^{-1}$ SM-amended soils with plants incubated under an 18/6 h day /night cycle at $24{ }^{\circ} \mathrm{C}$. For each rootstock genotype, three individual plants were transplanted into each pot as a sample pool, with 3 replicate pots for each rootstock (M.26 and G.210) $\times$ soil treatment (control and SM $4.4 \mathrm{t} \mathrm{ha}^{-1}$ ) for each timepoint. Roots and rhizosphere soils were harvested at $48 \mathrm{~h}, 72 \mathrm{~h}, 7 \mathrm{~d}$, and 2 months post-planting. Root samples harvested at $48 \mathrm{~h}, 72 \mathrm{~h}$, and $7 \mathrm{~d}$ post-planting were subjected to transcriptome sequencing analysis. DNA extracted from the rhizosphere soil (described below) was used for 16S rRNA amplicon sequencing and q-PCR based microbial quantification. Plants harvested at 2 months post-planting were used for assessing plant biomass and lesion nematode root infection.

\subsection{Treatment Effects on Plant Biomass and P. penetrans Root Density}

Plant biomass was measured prior to planting and at harvest ( 2 months post-planting). At harvest, roots were carefully washed and a $0.5 \mathrm{~g}$ fine root sample was excised from each plant. Nematode extraction and quantification of P. penetrans root density and statistical analysis of data were conducted as previously described [19].

\subsection{Total RNA Isolation and High-Throughput Transcriptome Sequencing}

Root samples were flash frozen in liquid nitrogen and stored at $-80^{\circ} \mathrm{C}$ prior to RNA isolation. Tissue ( $2 \mathrm{~g} /$ sample) was ground to a fine powder in liquid nitrogen and total RNA was extracted according to method of Gasic et al. [32]. RNA samples were immediately purified using the RNeasy MinElute Cleanup Kit (Qiagen, Germantown, MD, USA) and quantified using a ND 1000 nanodrop spectrophotometer (NanoDrop Technologies, Wilmington, DE, USA). RNA integrity was assessed using Fragment Analyzer (Advanced Analytical Technologies, Ankeny, IA, USA) with the High Sensitivity RNA Analysis Kit. RNA samples with RNA Quality Numbers above 7 were used for RNA library preparation with the TruSeq Stranded mRNA Library Prep Kit (Illumina, San Diego, CA, USA). RNA sequencing was completed at the Washington State University-Spokane Genomics Core facility using Illumina sequencing (Illumina Hiseq 2500).

\subsection{RNA-Seq Analysis}

The apple reference genome Malus domestica v1.0 and associated annotation files were downloaded from Genome Database for Rosaceae (rosaceae.org, accessed on 24 February 2021 [33,34]). All Illumina transcriptome data were passed through FastQC v0.11.7 [35] per base sequence quality test, resulting in an average Phred score of 36. Data were then subjected to reference mapping and differential expression analysis using CLC Genomics Workbench (CLC GW) v9.5.3 (CLCBio, Cambridge, MA, USA). "Malus_x_domestica.v1.0.contigs.gff" was used as the reference genome and "Malus_x_domestica.v1.0.consensus_mRNA.fa" and "Malus_x_domestica.v1.0.consensus_CDS.fa" were loaded as tracks. CLC GW reference Mapper was run with high stringency, the minimum length fraction was 0.8 and the minimum similarity was 0.8 . The limit for read unspecific match to Malus domestica v1.0 was set to 10. Expression values were created using the total number of reads mapped to the gene. The experiment was set up to define the relationship between samples, and the control and SM samples were compared for each rootstock genotype at each timepoint as described in Table 1. 
Table 1. Comparison groups and the number of identified differentially expressed genes (DEG).

\begin{tabular}{|c|c|c|c|c|c|}
\hline $\begin{array}{l}\text { Sampling } \\
\text { Timepoint }\end{array}$ & $\begin{array}{c}\text { Apple Rootstock } \\
\text { Genotype }\end{array}$ & Comparisons $^{\mathrm{z}}$ & No. of DEG & $\begin{array}{c}\text { No. of } \\
\text { Upregulated y }\end{array}$ & $\begin{array}{c}\text { No. of } \\
\text { Downregulated }\end{array}$ \\
\hline \multirow[b]{2}{*}{$48 \mathrm{~h}$} & M.26 & M.26-48 h-NTC vs. M.26 48 h-SM & 7 & 6 & 1 \\
\hline & G.210 & G.210-48 h-NTC vs. G.210-48 h-SM & 6 & 2 & 4 \\
\hline \multirow{2}{*}{$72 \mathrm{~h}$} & M.26 & M.26-72 h-NTC vs. M.26 72 h-SM & 122 & 64 & 58 \\
\hline & G.210 & G.210-72 h-NTC vs. G.210-72 h-SM & 177 & 106 & 71 \\
\hline \multirow[b]{2}{*}{$7 \mathrm{~d}$} & M.26 & M.26-7 d-NTC vs. M.26-7 d-SM & 10 & 6 & 4 \\
\hline & G.210 & G.210-7 d-NTC vs. G.210-7 d-SM & 232 & 33 & 199 \\
\hline
\end{tabular}

${ }^{\mathrm{z}}$ NTC $=$ no treatment control; SM $=$ Brassicaceae seed meal formulation of Brassica juncea/Sinapis alba (1:1) at a rate of $4.4 \mathrm{t} \mathrm{ha}^{-1}, \mathrm{y}$ DEG were categorized as upregulated where expression was higher in plants cultivated in seed meal (SM)-amended soil relative to that observed in plants cultivated in the no treatment control soil. Downregulated indicates that expression was higher in plants cultivated in control versus SM-amended soil.

The empirical analysis tool of differentially expressed genes (DEG) in CLC GW, which implements the "Exact Test" for two-group comparisons [36], was used to analyze DEG between control and SM treatments. Genes were described as up or down regulated in plant root tissue cultivated in SM-treated soil relative to non-treated controls. The absolute value of $\log 2$ fold change $(\mathrm{FC}) \geq 2$ and False Discovery Rate $(\mathrm{FDR})<0.001$ were selected as stringent thresholds to minimize false positives.

The Gene Ontology (GO) and the Kyoto Encyclopedia of Genes and Genomes (KEGG) annotations were extracted from 'Malus_x_domestica_v1.0.genes2GO" and "Malus_x_dom estica_v1.0.genes2KEGG_pathways" using the match function in $\mathrm{R}$ (ver. 3.4.1).

Functional enrichment analysis for GO biological process terms for genes of interest was performed using Fisher's Exact test in $\mathrm{R}$ with all predicted apple genes as the gene universe; alpha was set to 0.05 . The annotation of protein function encoded by these genes was conducted by blast $X\left(E-v a l u e ~ \leq 1.0 \times \mathrm{e}^{-9}\right)$ against UniprotKB/Swiss-Prot (swissprot) database with the blast+ package ([37]; http:/ /www.ncbi.nlm.nih.gov/BLAST /, accessed on 24 February 2021).

A separate analysis was performed to assess how G.210 and M.26 differed in their reactions when cultivated in ARD-conducive NTC soil. This analysis was performed using slightly different methodology as RNA-seq analysis procedures continue to evolve; in fact complementary methods may even be preferable [38]. Differential expression analysis of RNA-Seq data was performed on non-normalized raw counts of sequencing reads using the DESeq2 package in R version 3.5.3 [39]. All samples were of the same condition and included three biological replicates of each genotype at each timepoint. The BenjaminiHochberg (BH) adjustment was used to calculate an adjusted $p$-value with a false discovery rate of less than $1 \%$ ( $\mathrm{P}$ adj $<0.01)$. The topGO Bioconductor package in $\mathrm{R}$ was used to perform functional enrichment analysis on significantly upregulated and downregulated Gene Ontology (GO) terms [40]. Fisher's exact test (algorithm = "weight01") was used to test for statistical significance. "Malus_x_domestica_v1.0.genes2IPR.txt" was used for protein functional annotation.

\subsection{Validation of DEG Expression Patterns by Real-Time RT-qPCR}

Further analysis of 22 genes differentially expressed between NTC and SM treatments based on RNA-Seq were selected for validation with qRT-PCR. Forward and reverse primers were designed using web-based PrimerQuest Tool and oligo analyzer at Integrated DNA Technologies (idtdna.com). Primers were designed to possess an optimum annealing temperature of $60^{\circ} \mathrm{C}$, GC content of 40-60\%, amplicon length of 150-200 bp, and primer length of 20-24 bp. Candidate primers were aligned to the apple genome v1.0 predicted CDS (coding sequences) using BLASTn (rosaceae.org/tools/ncbi_blast, accessed 9 April 2019) to screen for primers with off-target binding sites.

DNase-treated RNA ( $2 \mu \mathrm{g})$ was used to synthesize first-strand cDNA using SuperScript II reverse transcriptase (Invitrogen, Grand Island, NY, USA) and poly dT (Operon, Huntsville, AL, USA) as the primer. The cDNA was diluted 20 times and a $2.4 \mu \mathrm{L}$ aliquot 
was used in a $15 \mu \mathrm{L}$ quantitative PCR (qPCR) reaction mix: $7.5 \mu \mathrm{L}$ SYBR Green PCR Master Mix (Applied Biosystems, Warrington, UK), $0.6 \mu \mathrm{L}$ of $10 \mu \mathrm{M}$ forward/reverse primer (IDT, Coralville, IA, USA), and 3.9 $\mu \mathrm{L}$ nanopure water. Real-time q-PCR was conducted using a StepOnePlus Real-Time PCR System (Applied Biosystems, Foster City, CA, USA) and the following protocol: a single cycle of $10 \mathrm{~min}$ at $95^{\circ} \mathrm{C}$ followed by 40 cycles of $15 \mathrm{~s}$ at $95{ }^{\circ} \mathrm{C}$ and $30 \mathrm{~s}$ at $55-60{ }^{\circ} \mathrm{C}$. Relative gene expression was measured using the non-treated control group as the calibrator. No reverse transcriptase and no template negative controls were included in every PCR amplification. Each sample was represented by two independent total RNA isolations converted into two separate cDNAs. Each cDNA sample was included using three technical replicates for PCR reactions. The target gene expression was normalized to that of the internal reference gene (MdActin) using the $2^{-\Delta \Delta C T}$ method [41].

\subsection{Quantification of Microbial Density in the Rhizosphere}

DNA was extracted from a 50-mg root tissue with adhering rhizosphere soil sample using the Mo-Bio plant DNA extraction kit (Mo-Bio, Carlsbad, CA, USA). Relative density of total fungi and bacteria in the samples was assessed by q-PCR. Time zero density of bacteria and fungi from plantlet roots was assessed using plantlets harvested directly from the potting mix without subsequent transplantation into soil.

The primer sets NSI1 [42]/5.8 S [43] and EU338F/EU518R [44] were used to amplify fungal ITS 1 and $5.8 \mathrm{~S}$ regions and bacterial $16 \mathrm{~S}$ rDNA region, respectively. Quantification was conducted using the StepOnePlus Real-Time PCR System, with the following protocol; initial denaturation for $10 \mathrm{~min}$ at $95^{\circ} \mathrm{C}$, followed by 40 cycles of $30 \mathrm{~s}$ at $95^{\circ} \mathrm{C}, 30 \mathrm{~s}$ at $58{ }^{\circ} \mathrm{C}$, and $30 \mathrm{~s}$ at $72^{\circ} \mathrm{C}$ for total fungi; and denaturation for $10 \mathrm{~min}$ at $95^{\circ} \mathrm{C}$, followed by 40 cycles of $30 \mathrm{~s}$ at $95^{\circ} \mathrm{C}$ and $45 \mathrm{~s}$ at $62^{\circ} \mathrm{C}$ for total bacteria. PCR reactions contained $1 \mu \mathrm{L}$ of 1:100 diluted DNA extract, $3 \mu \mathrm{L}$ SYBR Green PCR Master Mix (Applied Biosystems, Warrington, $\mathrm{UK}), 0.05 \mu \mathrm{L}$ forward/reverse primer and $5.9 \mu \mathrm{L}$ nanopure water. Standard curves were generated for PCR quantification using purified DNA from Fusarium oxysporum isolate 1208 and Pseudomonas florescence isolate SS101 for fungi and bacteria, respectively. Dilutions were prepared to generate DNA concentrations from 0.001 to $100 \mathrm{pg} \mu \mathrm{L}-1$. Each set of qPCR reactions included a no template control and all reactions were performed in triplicate.

\section{7. $16 S$ rRNA Sequencing of Rhizosphere DNA}

PCR amplification, purification of amplicons, library preparation, and bacterial sequencing were conducted at an external facility (Molecular Research, Shallowater, TX, USA) on a MiSeq platform as previously described [19]. Final OTUs were taxonomically classified using BLASTn against a curated database derived from GreenGenes, RDPII, and NCBI (rdp.cme.msu.edu, ncbi.nlm.nih.gov, accessed 19 January 2019). Explicet software [45] was used to conduct statistical analysis and visualization of bacterial sequence data. Alpha diversity was determined using the minimum library size as the default with 1000-bootstrap resampling. Beta diversity was assessed using the Bray-Curtis similarity distance metric. A two-part test [46] was conducted after making filters for each library of soil treatment and sample time, as well as comparing them with each other with a $P$ threshold of 0.05 .

\section{Results}

\subsection{Influence of Brassicaceae SM Amendment on Plant Growth and P. penetrans Root Density}

Rootstock vegetative growth was significantly $(p<0.001)$ affected by soil treatment but not rootstock genotype $(p=0.736)$. Rootstocks grown in SM-treated soil possessed greater total biomass than rootstocks grown in NTC soil (Figure 1A). Enhanced plant biomass was associated with a significant $(p<0.001)$ reduction in Pratylenchus penetrans root density in SM-treated soil relative to the NTC for both rootstock genotypes (Figure 1B). 


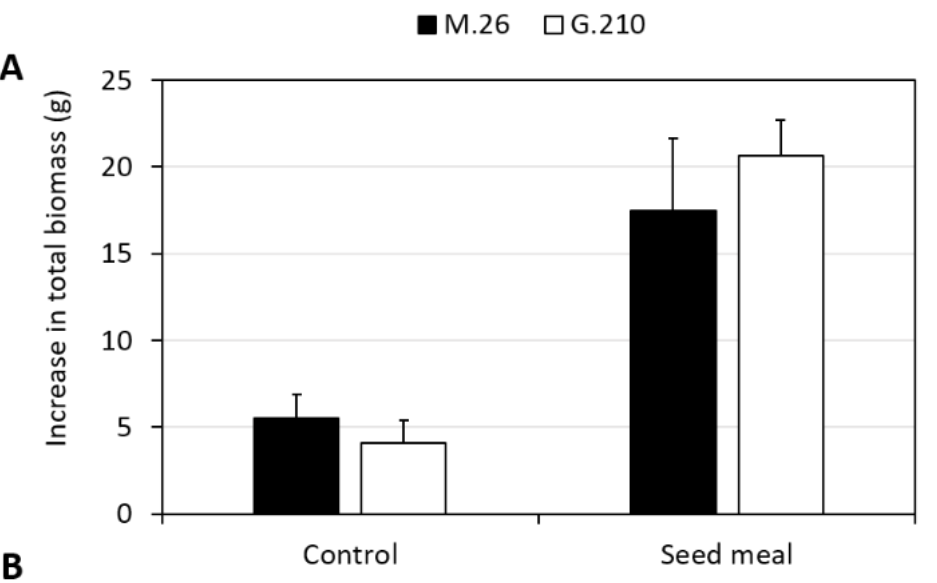

B

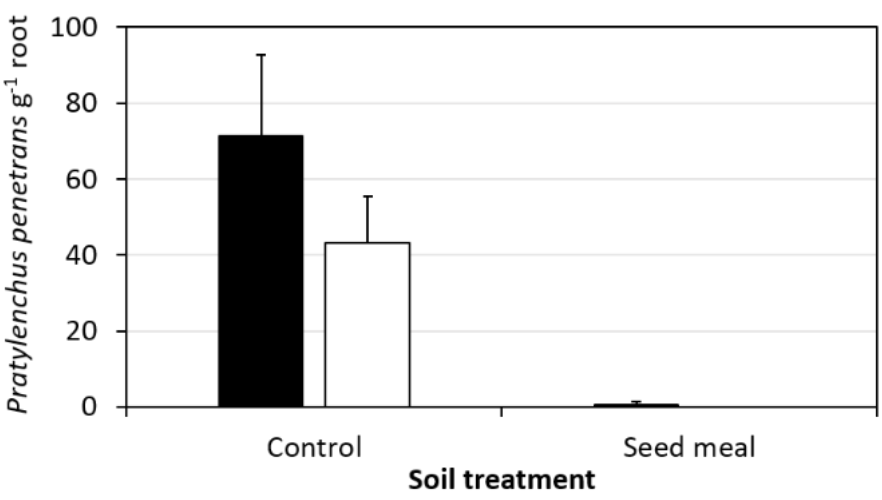

Figure 1. Effect of Brassicaceae seed meal soil treatment on total vegetative growth of plants (A) and the density of root lesion nematode, Pratylenchus penetrans, recovered from apple rootstock roots (B) at 2 months post-planting. Bars represent one standard error $(n=3)$. Seed meal = Brassicaceae seed meal formulation of Brassica juncea/Sinapis alba (1:1) at a rate of $4.4 \mathrm{t} \mathrm{ha}^{-1}$; Control = no treatment control.

\subsection{Mapping Statistics and Differential Gene Expression}

RNA sequencing produced an average of $\sim 33$ million reads per biological replicate. Overall, $92 \%$ of the reads were mapped to the apple genome with $69 \%$ mapping to known exons (Supplementary Materials Table S1). The soil treatment effect on gene expression was compared at each timepoint for the two rootstock genotypes (Table 1). A total of 554 differentially expressed genes (DEG) were identified (FDR $<0.001, \log _{2} \mathrm{FC}>2$ ) and differential regulation refers to SM-amendment versus the NTC. Differential gene expression overall in response to SM amendment was observed in both rootstocks, but was of greater magnitude in G.210 than in M.26, with 415 DEG and 139 DEG, respectively (Table 1). Further, the transcriptional modulation through time had a treatment-specific character. At $48 \mathrm{~h}$ post-planting the transcriptional response was relatively low for both genotypes (M.26 DEG = 6, G.210 DEG = 7; Table 1). For M.26, the number of DEG was greatest at $72 \mathrm{~h}$ (\# DEG =122), yet patterns of gene expression were more convergent again by $7 \mathrm{~d}$ with only 10 DEG (Table 1), indicating a large amount of functional similarity between M.26 roots growing in NTC and SM-amended soils at this later timepoint. This contrasts with the transcriptional reprogramming in the G.210 rootstock that was similar in magnitude at $72 \mathrm{~h}(\mathrm{DEG}=177)$, yet continued to diverge after an additional $7 \mathrm{~d}(\mathrm{DEG}=232$; see Table 1$)$. Overall, the dominant signature that differentiated the rootstock treatments was a $\sim 6$-fold greater number of downregulated genes in G.210 at the end of the experiment (Table 1). 


\subsection{Gene Ontology (GO) Enrichment Analysis of Biological Processes}

\subsubsection{ARD Susceptible Genotype M.26}

A functional enrichment (of Gene Ontology terms) showed the GO biological process (BP) term "transmembrane transport" was significantly enriched among up- and downregulated genes in the M.26 genotype $(p<0.001)$ (Figure 2). The GO BP term "response to stress" ( $p=0.024)$ was significantly enriched among upregulated genes in M.26 and the GO BP term "oxidation-reduction process" $(p=0.018)$ was enriched among downregulated genes (Figure 2A). Although "defense response" and "chitin catabolic process" were not significantly enriched, they were unique among upregulated DEG. These unique GO BP terms included genes involved in multiple aspects of plant inducible immune responses from pathogen recognition (e.g., disease resistance and pathogen recognition proteins), to signal transduction $\left(\mathrm{Ca}^{2+}\right.$-binding proteins and protein kinases) and hormone-mediated downstream defense responses (Ethylene-responsive transcription factor) (Table 2). For example, two important serine/threonine-protein kinases, CTR1 (MDP0000198976) and PBL27 (MDP0000273596), were accumulated to higher levels in M.26 cultivated in SM treatment at $72 \mathrm{~h}$ post-planting (Table 2). CTR1 is a negative regulator of the ethylene (ET) response pathways in Arabidopsis [47], and PBL27 is involved in the signal transduction of chitin-induced immunity [48]. Among downregulated DEG in M.26, unique GO BP terms were "cell wall modification" and "cell death process" (Figure 2A). Taken together, these results provide evidence of a role for SM in modulating phytohormone signaling pathways and inducible defense responses in M.26 at $72 \mathrm{~h}$ post-planting. Transcriptional changes also suggest that $\mathrm{SM}$-amendment was effective at reducing cellular damage in comparison to the NTC at this relatively early timepoint.

A

B

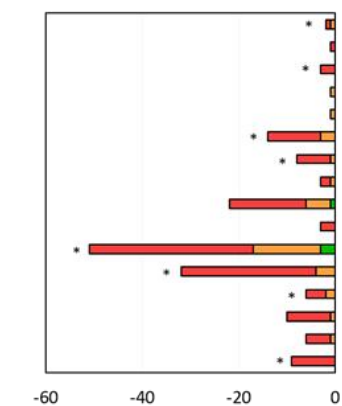

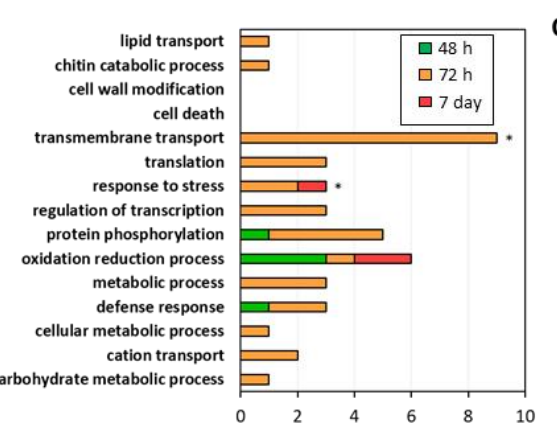

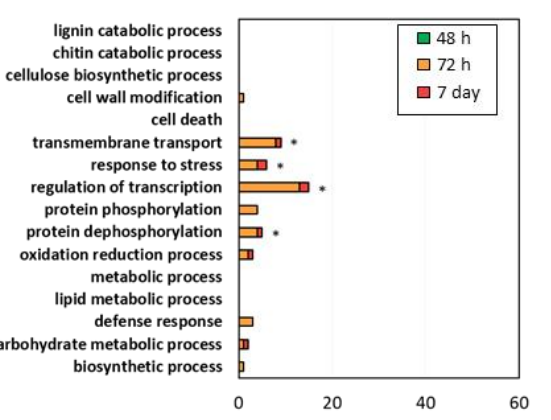

C

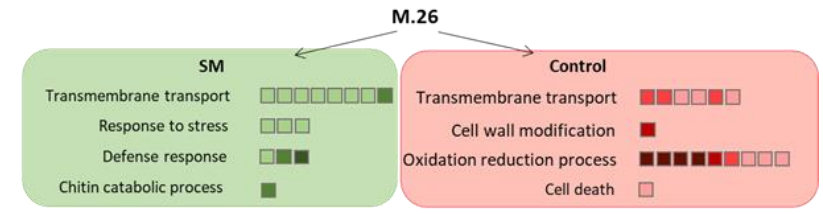

G.210

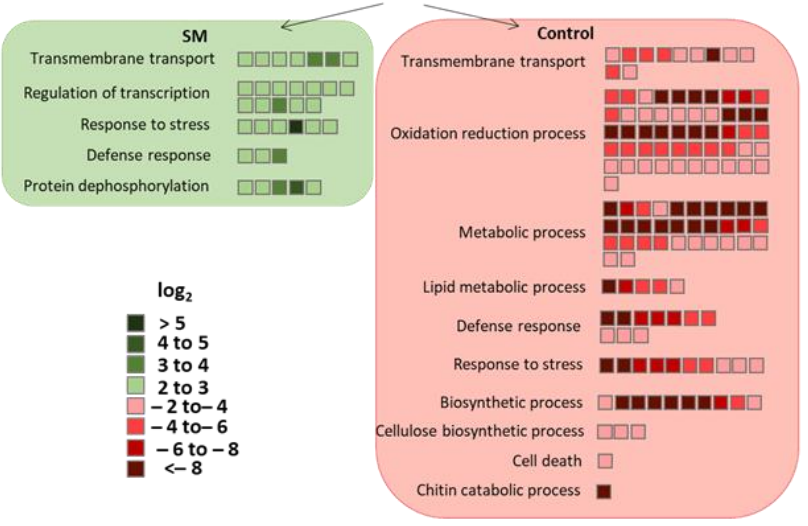

Figure 2. Major categories in Gene Ontology (GO) biological processes of the identified differentially expressed genes (DEG) in apple rootstocks M.26 (A) and G.210 (B); and fold changes of DEG in the major biological processes (C). Left panel of A and B represent processes annotated to downregulated DEG (lower in SM-amended versus control soil), and the right panel represents processes annotated to upregulated DEG (higher in SM-amended versus control soil). The $X$ axis represents number of DEG and the $\mathrm{Y}$ axis indicates the selected GO biological processes. Bars with * are significantly $(p \leq 0.05)$ enriched as assessed by GO enrichment analysis. 
Table 2. Selected genes differentially expressed in apple rootstock M.26 when planted in SM-amended replant orchard soil relative to non-treated orchard soil, with annotated function.

\begin{tabular}{|c|c|c|c|}
\hline Gene ID in GDR ${ }^{z}$ & Protein Function Annotation ${ }^{y}$ & $\log _{2}(\mathrm{FC})^{x}$ & Timepoint \\
\hline MDP0000196909 & TMV resistance protein $\mathrm{N}$ & 2.03 & $48 \mathrm{~h}$ \\
\hline MDP0000711750 & CBL-interacting serine/threonine-protein kinase 12 & -2.61 & $48 \mathrm{~h}$ \\
\hline MDP0000306089 & Calcium-binding EF-hand family protein & 2.33 & $72 \mathrm{~h}$ \\
\hline MDP0000283789 & Disease resistance protein RGA3 & 1.94 & $72 \mathrm{~h}$ \\
\hline MDP0000162375 & Disease resistance protein & 2.31 & $72 \mathrm{~h}$ \\
\hline MDP0000683814 & Ethylene-responsive transcription factor RAP2-4 & 2.49 & $72 \mathrm{~h}$ \\
\hline MDP0000278380 & Pathogenesis-related protein 5 & 2.88 & $72 \mathrm{~h}$ \\
\hline MDP0000198976 & Serine/threonine-protein kinase CTR1 & 5.56 & $72 \mathrm{~h}$ \\
\hline MDP0000273596 & Serine/threonine-protein kinase PBL27 & 2.17 & $72 \mathrm{~h}$ \\
\hline MDP0000268026 & TMV resistance protein $\mathrm{N}$ & 3.33 & $72 \mathrm{~h}$ \\
\hline MDP0000191786 & 4-coumarate-CoA ligase-like 5 & -5.46 & $72 \mathrm{~h}$ \\
\hline MDP0000185169 & Benzyl alcohol O-benzoyltransferase & -5.45 & $72 \mathrm{~h}$ \\
\hline MDP0000189033 & Ethylene-responsive transcription factor 2 & -4.13 & $72 \mathrm{~h}$ \\
\hline MDP0000234530 & MLO-like protein 6 & -10.06 & $72 \mathrm{~h}$ \\
\hline MDP0000266840 & NADP-dependent alkenal double bond reductase P2 & -2.66 & $72 \mathrm{~h}$ \\
\hline MDP0000231619 & Probable pectinesterase/pectinesterase inhibitor 7 & -5.13 & $72 \mathrm{~h}$ \\
\hline MDP0000318604 & Probable S-adenosylmethionine-dependent methyltransferase & -2.85 & $72 \mathrm{~h}$ \\
\hline MDP0000675952 & Probable S-adenosylmethionine-dependent methyltransferase & -4.2 & $72 \mathrm{~h}$ \\
\hline MDP0000931970 & Receptor-like protein kinase THESEUS 1 & -2.38 & $72 \mathrm{~h}$ \\
\hline MDP0000755567 & Indole-3-acetic acid-induced protein ARG2 & 2.29 & $7 \mathrm{~d}$ \\
\hline
\end{tabular}

z Apple reference genome "Malus_x_domestica.v1.0.contigs.gff" was obtained from rosaceae.org, accessed on 24 February 2021, y Protein function annotation is based on the blastX search against UniprotKB/Swiss-Prot (swissprot) database from NCBI, ${ }^{\mathrm{x}}$ Variations in transcript abundance were based on comparison between control and seed meal treatments, and expressed as log fold change; ( + ) indicates upregulated, and (-) indicates downregulated, in rootstocks cultivated in seed meal-treated soil.

\subsubsection{ARD Tolerant Genotype G. 210}

Similar to M.26, in G.210 the GO BP terms significantly enriched in response to SM soil amendment at $72 \mathrm{~h}$ included "response to stress" $(p<0.001)$ and "transmembrane transport" ( $p<0.001)$, but also "regulation of transcription" $(p<0.001)$, and "protein dephosphorylation" ( $p<0.001)$ (Figure 2B). The GO BP Term "defense response" was also enriched among upregulated genes relative to the NTC at $72 \mathrm{~h}$. Several upregulated DEG encoded proteins that may influence responses to various biotic and abiotic stressors include Abscisic acid-insensitive 5-like protein (MDP0000296303; 72 h), a CBL-interacting serine/threonine-protein kinase 9 (MDP0000216765; 72 h), and calcium sensors (Table 3).

Apple replant disease causal pathogens, Ilyonectria, Pythium, Phytophthora, Rhizoctonia, and P. penetrans, represent major sources of biotic stress in the rhizosphere and roots of plants. When challenged with these soil-borne pathogens, plant roots typically exhibit the JA/ET-dependent defenses [49-52], but not SA-dependent defense responses. Therefore, it is notable that two genes encoding NINJA-family proteins (MDP0000119875; MDP0000875341) which repress jasmonate responses [53], were also upregulated in G.210 at the 72-h timepoint (Table 3). Interestingly, Abscisic acid 8'-hydroxylase was 10-fold higher when G.210 was cultivated in NTC relative to SM-amended soil at $72 \mathrm{~h}$. Abscisic acid (ABA) 8-hydroxylase catalyzes the first step in the oxidative degradation of (+)-ABA. In Arabidopsis, ABA deficiency resulted in upregulation of basal and induced transcription from JA-ethylene responsive defense genes [53]. Together, these findings point to SM-mediated suppression of JA signaling in G.210.

As mentioned above, the total number of DEG between the two soil treatments was much larger in the disease tolerant G.210 rootstock $(=232)$ compared to the susceptible rootstock M.26 (=10) at $7 \mathrm{~d}$. In contrast to the 72-h timepoint, a relatively higher number of DEG annotated with the GO BP term "defense response" were expressed in G.210 in control soils with higher disease pressure. The G.210 rootstock showed significant functional enrichment among downregulated genes for GO BP terms "oxidation reduction process" $(p<0.001)$, "response to stress" $(p<0.001)$, "transmembrane transport" $(p=0.036)$, "metabolic process" ( $p<0.001)$, "biosynthetic process" ( $p=0.001)$, "cellulose biosynthesis" $(p=0.049)$ and "lignin catabolic process" ( $p=0.040$; Figure 2B). Significant enrichment of the GO BP terms involved in cell wall-related processes in the NTC treatment at $7 \mathrm{~d}$ in 
G.210 (but not in M.26) may reflect genotype-specific mechanisms of resistance (i.e., high rates of root growth in G.210 = greater resilience to root loss) (Figure 2B). In addition, at $7 \mathrm{~d}$, six downregulated DEG in G.210 encoded protein DMR6-like oxygenase, which functions as a negative regulatory component of SA signaling. In Arabidopsis, DMR6 mutants lost susceptibility to downy mildew, caused by Hyaloperonospora arabidopsis, and exhibited enhanced resistance to P. syringae and Phytophthora capsici [54].

Table 3. Selected genes differentially expressed in apple rootstock G.210 when planted in SM-amended replant orchard soil relative to non-treated orchard soil, with annotated function.

\begin{tabular}{|c|c|c|c|}
\hline Gene ID in GDR ${ }^{z}$ & Protein Function Annotation ${ }^{y}$ & $\log _{2}(\mathrm{FC})^{x}$ & Timepoint \\
\hline MDP0000319359 & Calcium-dependent lipid-binding (CaLB domain) family protein & 6.41 & $48 \mathrm{~h}$ \\
\hline MDP0000296303 & Abscisic acid-insensitive 5 -like protein & 2.17 & $72 \mathrm{~h}$ \\
\hline MDP0000306089 & Calcium-binding EF-hand family protein & 2.51 & $72 \mathrm{~h}$ \\
\hline MDP0000216765 & CBL-interacting serine/threonine-protein kinase 9 & 2.19 & $72 \mathrm{~h}$ \\
\hline MDP0000127009 & Disease resistance protein RGA2 & 1.82 & $72 \mathrm{~h}$ \\
\hline MDP0000137225 & Disease resistance protein & 3.02 & $72 \mathrm{~h}$ \\
\hline MDP0000640906 & Disease resistance protein & 2.95 & $72 \mathrm{~h}$ \\
\hline MDP0000162375 & Disease resistance protein & 2.22 & $72 \mathrm{~h}$ \\
\hline MDP0000228070 & 9-cis-epoxycarotenoid dioxygenase & 8.60 & $72 \mathrm{~h}$ \\
\hline MDP0000929213 & 9-cis-epoxycarotenoid dioxygenase & 3.68 & $72 \mathrm{~h}$ \\
\hline MDP0000484601 & GTP-binding protein brassinazole insensitive pale green 2 & 1.89 & $72 \mathrm{~h}$ \\
\hline MDP0000290028 & LRR receptor-like serine/threonine-protein kinase GSO2 & 4.90 & $72 \mathrm{~h}$ \\
\hline MDP0000119875 & Ninja-family protein AFP2 & 2.37 & $72 \mathrm{~h}$ \\
\hline MDP0000875341 & Ninja-family protein AFP3 & 4.79 & $72 \mathrm{~h}$ \\
\hline MDP0000588503 & Pathogenesis-related protein 10 & 2.18 & $72 \mathrm{~h}$ \\
\hline MDP0000234689 & S-type anion channel SLAH3 & 3.23 & $72 \mathrm{~h}$ \\
\hline MDP0000268026 & TMV resistance protein $\mathrm{N}$ & 2.59 & $72 \mathrm{~h}$ \\
\hline MDP0000657441 & WRKY transcription factor 68 & 2.47 & $72 \mathrm{~h}$ \\
\hline MDP0000166337 & Abscisic acid $8^{\prime}$-hydroxylase 4 & -9.91 & $72 \mathrm{~h}$ \\
\hline MDP0000197409 & Carotenoid cleavage dioxygenase 7 & -3.39 & $72 \mathrm{~h}$ \\
\hline MDP0000139334 & Carotenoid cleavage dioxygenase 7 & -3.47 & $72 \mathrm{~h}$ \\
\hline MDP0000652331 & Cytochrome b561 and DOMON & -2.24 & $72 \mathrm{~h}$ \\
\hline MDP0000138669 & Ethylene-responsive transcription factor RAP2-11 & -6.41 & $72 \mathrm{~h}$ \\
\hline MDP0000295857 & Fusaric acid resistance protein & -4.77 & $72 \mathrm{~h}$ \\
\hline MDP0000239643 & MLO-like protein 6 & -3.88 & $72 \mathrm{~h}$ \\
\hline MDP0000266930 & NADPH-dependent oxidoreductase 2-alkenal reductase & -3.17 & $72 \mathrm{~h}$ \\
\hline MDP0000872370 & NADPH-dependent oxidoreductase 2-alkenal reductase & -3.00 & $72 \mathrm{~h}$ \\
\hline MDP0000675952 & Probable S-adenosylmethionine-dependent methyltransferase & -5.92 & $72 \mathrm{~h}$ \\
\hline MDP0000261194 & Probable S-adenosylmethionine-dependent methyltransferase & -6.22 & $72 \mathrm{~h}$ \\
\hline MDP0000729108 & Pathogenesis-related protein 10 & -11.18 & $72 \mathrm{~h}$ \\
\hline MDP0000296675 & Protein LURP-one-related 4 & $-\infty$ & $72 \mathrm{~h}$ \\
\hline MDP0000930978 & Protein SAR deficient 1 & -10.33 & $72 \mathrm{~h}$ \\
\hline MDP0000139821 & Disease resistance protein & $-2.48 /-2.32$ & $72 \mathrm{~h} / 7 \mathrm{~d}$ \\
\hline MDP0000309171 & Disease resistance protein & $-2.82 /-3.34$ & $72 \mathrm{~h} / 7 \mathrm{~d}$ \\
\hline MDP0000792101 & Wound-induced protein & $-5.45 /-5.61$ & $72 \mathrm{~h} / 7 \mathrm{~d}$ \\
\hline MDP0000275716 & Cellulose synthase-like protein B4 & -3.35 & $7 \mathrm{~d}$ \\
\hline MDP0000411073 & Cellulose synthase-like protein E2 & -3.91 & $7 \mathrm{~d}$ \\
\hline MDP0000221346 & Cellulose synthase-like protein G2 & -3.33 & $7 \mathrm{~d}$ \\
\hline MDP0000314000 & Cysteine-rich receptor-like protein kinase 29 & -3.43 & $7 \mathrm{~d}$ \\
\hline MDP0000685403 & Cysteine-rich receptor-like protein kinase 29 & -10.06 & $7 \mathrm{~d}$ \\
\hline MDP0000927688 & Cysteine-rich repeat secretory protein 38 & -7.61 & $7 \mathrm{~d}$ \\
\hline MDP0000416561 & Cysteine-rich repeat secretory protein 38 & -8.13 & $7 \mathrm{~d}$ \\
\hline MDP0000842997 & $\mathrm{ABC}$ transporter $\mathrm{C}$ family member 3 & -2.79 & $7 \mathrm{~d}$ \\
\hline MDP0000865714 & Disease resistance protein & -16.43 & $7 \mathrm{~d}$ \\
\hline MDP0000706371 & Disease resistance protein & -2.73 & $7 \mathrm{~d}$ \\
\hline MDP0000126026 & Disease resistance protein & -3.37 & $7 \mathrm{~d}$ \\
\hline MDP0000224187 & Disease resistance RPP13-like protein 4 & -3.27 & $7 \mathrm{~d}$ \\
\hline MDP0000193383 & Endochitinase EP3 & -10.32 & $7 \mathrm{~d}$ \\
\hline MDP0000143462 & Glycine-rich cell wall structural protein & -13.37 & $7 \mathrm{~d}$ \\
\hline MDP0000260110 & Major allergen Mal d 1 & -3.06 & $7 \mathrm{~d}$ \\
\hline MDP0000831518 & Major allergen Mal d 1 & -4.14 & $7 \mathrm{~d}$ \\
\hline MDP0000831519 & Major allergen Mal d 1 & -4.46 & $7 \mathrm{~d}$ \\
\hline MDP0000295542 & Major allergen Mal d 1 & -5.61 & $7 \mathrm{~d}$ \\
\hline MDP00008664747 & Major allergen Mal d 1 & -7.23 & $7 \mathrm{~d}$ \\
\hline MDP0000313454 & Major allergen Pru ar 1 & -9.78 & $7 \mathrm{~d}$ \\
\hline MDP0000124524 & Pathogenesis-related protein STH-2 & -6.88 & $7 \mathrm{~d}$ \\
\hline MDP0000119517 & Pathogenesis-related protein STH-2 & -7.37 & $7 \mathrm{~d}$ \\
\hline
\end{tabular}


Table 3. Cont.

\begin{tabular}{|c|c|c|c|}
\hline Gene ID in GDR ${ }^{z}$ & Protein Function Annotation $\mathrm{y}$ & $\log _{2}(\mathrm{FC})^{x}$ & Timepoint \\
\hline MDP0000221319 & Pectin acetylesterase 8 & -7.66 & $7 \mathrm{~d}$ \\
\hline MDP0000249386 & Polygalacturonase & 3.07 & $7 \mathrm{~d}$ \\
\hline MDP0000755567 & Indole-3-acetic acid-induced protein ARG2 & 2.39 & $7 \mathrm{~d}$ \\
\hline MDP0000683814 & Ethylene-responsive transcription factor RAP2-4 & 2.17 & $7 \mathrm{~d}$ \\
\hline MDP0000282421 & U-box domain-containing protein 9 & 1.94 & $7 \mathrm{~d}$ \\
\hline MDP0000897962 & Probable LRR receptor-like serine/threonine-protein kinase & -2.68 & $7 \mathrm{~d}$ \\
\hline MDP0000229843 & Protein DMR6-like oxygenase & -5.85 & $7 \mathrm{~d}$ \\
\hline MDP0000576922 & Protein DMR6-like oxygenase & -3.28 & $7 \mathrm{~d}$ \\
\hline MDP0000218810 & Protein DMR6-like oxygenase & -3.34 & $7 \mathrm{~d}$ \\
\hline MDP0000593536 & Protein DMR6-like oxygenase & -3.67 & $7 \mathrm{~d}$ \\
\hline MDP0000566057 & Protein DMR6-like oxygenase & -4.53 & $7 \mathrm{~d}$ \\
\hline MDP0000147913 & Protein DMR6-like oxygenase & -5.70 & $7 \mathrm{~d}$ \\
\hline MDP0000694318 & Rust resistance kinase Lr10 & -5.93 & $7 \mathrm{~d}$ \\
\hline MDP0000156351 & U-box domain-containing protein 21 & -4.99 & $7 \mathrm{~d}$ \\
\hline MDP0000206106 & Wall-associated receptor kinase & -7.21 & $7 \mathrm{~d}$ \\
\hline
\end{tabular}

z Apple reference genome "Malus_x_domestica.v1.0.contigs.gff" was obtained from rosaceae.org, accessed on 24 February 2021, y Protein function annotation is based on the blastX search against UniprotKB/Swiss-Prot (swissprot) database from NCBI, ${ }^{\mathrm{x}}$ Variations in transcript abundance were based on comparison between control and seed meal treatments, and expressed as log fold $_{2}$ change; ( + ) indicates upregulated, and (-) indicates downregulated, in rootstocks cultivated in seed meal-treated soil.

\subsection{KEGG Pathway Analysis and the Role of Secondary Metabolism}

\subsubsection{ARD Susceptible Genotype M.26}

To further understand the functions of DEG involved in metabolic and/or signal transduction pathways, all of the DEG were mapped to KEGG pathways (Figure 3). In M.26, the peak transcriptional reprogramming associated with cultivation in SM-amended soil occurred $72 \mathrm{~h}$ post-planting. Many upregulated DEG in M.26 mapped to KEGG pathways involved in amino acid metabolism (Figure 3A), which is tightly linked to many other metabolic pathways, including nutrient and energy metabolism, secondary metabolism, and stress response. Additionally, upregulated DEG mapped to KEGG pathways for sulfur and nitrogen metabolism. Consistent with the GO BP analysis, DEG which mapped to Plantpathogen interaction and Phagosome were also upregulated at this time (Figure 3A). In comparison, downregulated DEG mapped to KEGG pathways for amino acid metabolism, sugar, and carbohydrate metabolism, as well as the biosynthesis of secondary metabolites (i.e., Terpenoid backbone biosynthesis). By $72 \mathrm{~h}$, a number of DEG involved in phytohormone signaling and/or the utilization of secondary metabolites were upregulated in M.26 root tissue cultivated in NTC soil (Table 2). These included a putative 4-coumarate-CoA ligase (MDP0000191786) and 2 genes encoding probable S-adenosylmethionine-dependent methyltransferases (MDP0000318604 and MDP0000675952). 4-coumarate-CoA ligase contributes to JA biosynthesis, as well as to the synthesis and secretion of phenylpropanoids, while S-adenosylmethionine-dependent methyltransferase is an enzyme which methylates proteins in the biosynthesis of numerous secondary metabolites.

\subsubsection{ARD Tolerant Genotype G.210}

In G.210, similar to M.26, upregulated DEG which mapped to defense-related KEGG pathways were identified at $72 \mathrm{~h}$ : Plant-pathogen interaction and Plant hormone signal transduction (Figure 3B and Table 3). Many upregulated DEG also mapped to KEGG pathways associated with carbon and energy metabolism, including starch and sucrose metabolism, glycolysis/gluconeogenesis, and galactose metabolism. 
A
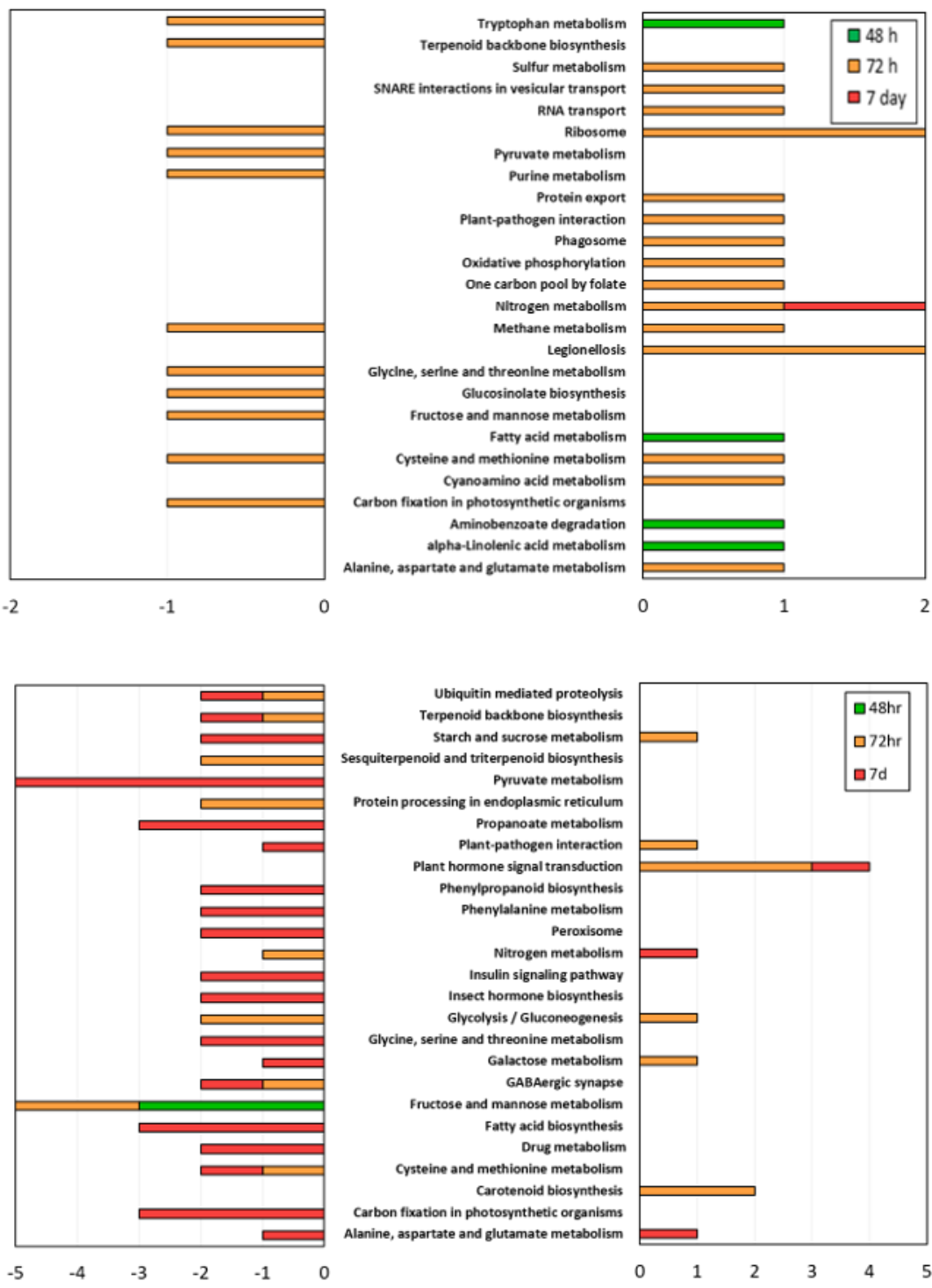

Figure 3. Major KEGG (Kyoto Encyclopedia of Genes and Genomes) pathways to which the identified differentially expressed genes (DEG) in apple rootstocks M.26 (A) and G.210 (B) were mapped. The left panel represents processes downregulated and right panel represents processes upregulated in the seed meal treatment. The $X$ axis indicates number of DEG and the $Y$ axis indicates the selected KEGG pathways.

At 7 days, gene activity was significantly lower in SM treatment (86\% of DEG were downregulated). Many of these downregulated DEG mapped to the same KEGG pathways to which upregulated DEG had mapped during the 72-h timepoint (e.g., starch and sucrose metabolism, nitrogen metabolism, and plant-pathogen interaction). Both DEG that mapped to Plant-pathogen interaction encoded proteins functioning in calcium ion binding. Consistent with the GO BP analysis, these findings suggest a defense response in the resistant genotype in both treatments, albeit at different times. Furthermore, the defense response in G.210 appears to have been larger in the NTC soil at 7 days than in the SM-amended soil at $72 \mathrm{~h}$ (Figure 3B). This is evidenced by the fold changes shown in Figure 2C, in which defense-related genes were induced to a greater degree in the roots of G.210 when grown in non-treated control soil (up to $<8$-fold), as compared to the SM-amended soil (up to 3-4-fold). In addition, downregulated DEG in G.210 mapped to primary metabolic pathways involved in carbohydrate and amino acid metabolism, as well as those involved in the metabolism of terpenoids, polyketides, and the biosynthesis of secondary metabolites 
(Figure 3B). The modulation of primary metabolic pathways to supply necessary substrates to secondary metabolic pathways is typically regulated in response to pathogen attack [55].

\subsection{DEG Identified in Both Rootstock Genotypes Cultivated in SM Amended Soil}

There were some commonalities in the gene expression response of both rootstock genotypes (DEG = 32) when cultivated in SM-amended soil. This was observed primarily after $72 \mathrm{~h}(\mathrm{DEG}=28)$ and the genes were annotated as related to disease stress response $(\mathrm{DEG}=8)$ and an additional 7 DEG functional in metal ion binding, DNA binding, lipid binding, and sugar transport. Among these may be common genetic factors that play a role in SM-induced response in both genotypes (see Table 4 for details). Notably, the disease response gene MDP0000570102 is involved in flavonoid biosynthesis, which may enhance localized auxin accumulation [56,57], and DNA binding gene MDP000190029 functions in enhancing auxin biosynthesis. Flavonoids reduce the production of reactive oxygen species (ROS) and protect plants against pathogens and herbivores [58]. Thus, these unique genes may be particularly important to triggering SM-induced defense responses, as well as to the broader response of the plant to SM.

Table 4. Functional annotation of genes exhibiting comparable pattern of differential expression between seed meal and non-treated replant orchard soils for both apple rootstock genotypes (M.26 and G.210).

\begin{tabular}{|c|c|c|c|c|}
\hline \multirow{2}{*}{ Gene ID in GDR ${ }^{z}$} & \multicolumn{2}{|c|}{$\log _{2}(F C)^{y}$ in } & \multirow{2}{*}{ Biological Process ${ }^{x}$} & \multirow{2}{*}{ Protein Function Annotation w } \\
\hline & M.26 & G.210 & & \\
\hline MDP0000306089 & 2.33 & 2.51 & Plant-pathogen interaction & Calcium-binding EF-hand family protein \\
\hline MDP0000162375 & 2.31 & 2.22 & Disease resistance & Disease resistance protein \\
\hline MDP0000268026 & 3.33 & 2.59 & Protein binding & $\mathrm{TMV}$ resistance protein $\mathrm{N}$ \\
\hline MDP0000302115 & 4.12 & 3.92 & $\mathrm{~N} / \mathrm{A}^{\mathrm{v}}$ & Disease resistance protein \\
\hline MDP0000570102 & 2.09 & 2.51 & Flavonoid biosynthetic process & $\mathrm{N} / \mathrm{A}$ \\
\hline MDP0000755567 & 2.29 & 2.39 & Response to stress & Late embryogenesis abundant like-5 (ATLEA5) \\
\hline MDP0000385497 & 2.14 & 2.12 & Response to stress & Late embryogenesis abundant like-5 (ATLEA5) \\
\hline MDP0000234689 & 2.62 & 3.23 & $\begin{array}{c}\text { Response to salt stress and water } \\
\text { deprivation }\end{array}$ & SLAC1 homologue 3 (SLAH3) \\
\hline MDP0000190029 & 2.06 & 2.06 & DNA binding & Nuclear factor Y, Subunit C2 \\
\hline MDP0000581293 & 2.76 & 2.12 & DNA binding & REVEILLE 1-like \\
\hline MDP0000153123 & 1.97 & 2.40 & Metal ion binding & Heme-binding protein \\
\hline MDP0000821892 & 1.91 & 2.34 & Metal ion binding & Metallothionein \\
\hline MDP0000212510 & 2.83 & 2.23 & Sugar transport & Monosaccharid transporter 2 \\
\hline MDP0000281884 & 2.70 & 2.56 & Sugar transport & Monosaccharid transporter 2 \\
\hline MDP0000403033 & 2.38 & 2.61 & Ion channel & Chloride channel C \\
\hline MDP0000307717 & 3.06 & 3.60 & Lipid transfer & Lipid-transfer protein \\
\hline MDP0000270246 & 2.45 & 2.13 & Protein insertion into membrane & Membrane protein \\
\hline MDP0000322201 & 2.69 & 2.44 & $\mathrm{~N}$-acetyltransferase & Acyl-CoA N-acyltransferases (NAT) superfamily protein \\
\hline MDP0000210084 & 2.77 & 2.94 & Involved in leaf vasculature patterning & Glycine-rich protein DOT1-like \\
\hline MDP0000827125 & 2.59 & 3.60 & $\mathrm{~N} / \mathrm{A}$ & $\mathrm{N} / \mathrm{A}$ \\
\hline MDP0000286637 & 2.62 & 3.24 & Transport & Integral membrane HPP family protein \\
\hline MDP0000239643 & -3.99 & -3.88 & Cell death & MLO family protein \\
\hline MDP0000171573 & -3.09 & -2.63 & Fructose and mannose metabolism & $\begin{array}{l}\text { GroES-like zinc-binding alcohol dehydrogenase family } \\
\text { protein }\end{array}$ \\
\hline MDP0000145305 & -2.81 & -3.75 & DNA replication initiation & Dienelactone hydrolase \\
\hline MDP0000675952 & -4.20 & -5.92 & Methyltransfer & Methyltransferase \\
\hline MDP0000258061 & -6.21 & -6.46 & Oxidation-reduction process & $\begin{array}{l}\text { 2-oxoglutarate (2OG) and Fe(II)-dependent oxygenase } \\
\text { superfamily protein }\end{array}$ \\
\hline MDP0000139947 & -6.11 & -5.058 & Protein phosphorylation & Protein kinase THE1 \\
\hline MDP0000870778 & -2.14 & -2.02 & Protein phosphorylation & Receptor-like protein kinase FERONIA \\
\hline MDP0000252274 & $-\infty$ & -2.61 & Isoprenoid biosynthetic process & Terpenoid synthase \\
\hline MDP0000295857 & -5.02 & -4.77 & Phosphate ion transmembrane transport & P-hydroxybenzoic acid efflux pump subunit \\
\hline MDP0000464148 & -3.01 & -3.18 & Integral component of membrane & Transmembrane protein \\
\hline MDP0000816071 & -7.76 & -6.15 & $\mathrm{~N} / \mathrm{A}$ & LOB domain-containing protein \\
\hline
\end{tabular}

z Apple reference genome "Malus_x_domestica.v1.0.contigs.gff" was obtained from rosaceae.org, accessed on 24 February 2021, y Variations in transcript abundance were based on comparison between control and seed meal treatments, and expressed as log 2 fold change; $(+)$ indicates upregulated, and (-) indicates downregulated, in the root of rootstocks cultivated in seed meal-treated soil, $\mathrm{x}$ Gene ontology biological process annotation was based on Malus_x_domestica_v1.0.genes2GO from rosaceae.org, accessed on 24 February 2021. w Protein function annotation is based on the blastX search against UniprotKB/Swiss-Prot (swissprot) database from NCBI. ${ }^{v}$ N/A = no annotated function. 


\subsection{Validation of the Expression Patterns of Selected DEG by q-PCR}

Expression patterns for 22 DEG were validated by q-PCR (Supplementary Materials Figures S1 and S2). Selected genes included those involved in various plant defense responses (MDP0000729108, MDP0000162375, MDP0000306089, MDP0000239643, MDP0000598998, MDP0000193383, MDP0000196909), cell wall modification (MDP0000281777, MDP0000231962, MDP0000411073), oxidation reduction (MDP0000629143, MDP0000214930, MDP0000258061, MDP0000181160), regulation of transcription (MDP0000296303, MDP0000581293), lipid transport (MDP0000307717), sugar transport (MDP0000212510), and protein phosphorylation (MDP0000172516). Gene expression patterns between RNA-Seq and qPCR were concordant (Supplementary Materials Figures S1 and S2).

\subsection{Effect of SM Treatment on the Root Zone Microbial Density Post-Planting}

Initially, population densities of fungi in the root zone of both rootstock cultivars were very low when cultivated in potting mix prior to transplanting in orchard soil $\left(<1.5 \mathrm{pg} \mathrm{mg}^{-1}\right.$ root). For both rootstocks, root zone fungal density in SM treatment did not significantly change from 0 to $72 \mathrm{~h}$ post-planting ( $<2.0 \mathrm{pg} \mathrm{mg}^{-1}$ root), but an increase was observed at 7 days. At 7 days, G.210 had roughly three times more fungal DNA per mg of root (17.1 $\mathrm{pg} \mathrm{mg}^{-1}$ root) than M.26 (5.4 $\mathrm{pg} \mathrm{mg}^{-1}$ root) when cultivated in SM-treated soil. The quantity of fungal DNA detected in the root zone of G.210 x NTC did not change significantly over the 7-day monitoring period (0.1-3.6 $\mathrm{pg} \mathrm{mg}^{-1}$ root). As a result, after 7 days, the G.210 x SM treatment had roughly 6X more fungal DNA than the G. $210 \times$ NTC treatment. In comparison, the quantity of fungal DNA detected in the root zone of M.26 cultivated in the NTC soil increased significantly from $1.3 \mathrm{pg} \mathrm{mg}^{-1}$ root at $48 \mathrm{~h}$ to $22.9 \mathrm{pg} \mathrm{mg}^{-1}$ at day 7 , resulting in the M.26 x SM treatment having roughly $5 \mathrm{X}$ less fungal DNA than the M.26 x NTC treatment.

The quantity of bacterial DNA detected in the root zone was both time and rootstock cultivar-dependent but did not appear to be treatment-dependent. In SM-amended soil, bacterial density in the root zone was greatest in M.26 at $48 \mathrm{~h}$ post-transplantation $\left(25,780 \mathrm{pg} \mathrm{mg}^{-1}\right.$ root), with a subsequent decline observed at the 7-day timepoint (9987 $\mathrm{pg} \mathrm{mg}^{-1}$ root). The same trend was observed for this rootstock when cultivated in the NTC soil with a peak density observed at $48 \mathrm{~h}\left(27,740 \mathrm{pg} \mathrm{mg}^{-1}\right.$ root $)$ and a significant decrease observed at $72 \mathrm{~h}\left(9543 \mathrm{pg} \mathrm{mg}^{-1}\right)$. In contrast, bacterial density in the root zone of G.210 cultivated in SM soil exhibited a gradual increase over time from $4843 \mathrm{pg} \mathrm{mg}^{-1}$ root at time 0 (in potting soil), and a similar trend was observed in the NTC soil. For G.210 rootstock, a comparable bacterial density was detected in the root zone for both soil treatments at 7 days $\left(\mathrm{NTC}=13,016 \mathrm{pg} \mathrm{mg}^{-1} ; \mathrm{SM}=11,052 \mathrm{pg} \mathrm{mg}^{-1}\right)$.

\subsection{Effect of SM Amendment and Rootstock Genotype on Bacterial Community Composition}

Across all timepoints, SM treatment had a significant effect on composition of the bacterial community relative to the NTC $\left(p=0.0001 \mathrm{R}_{\text {ANOSIM }}=0.673\right.$; Figure 4$)$. In the NTC soil, the root/rhizosphere bacterial community was highly similar in composition at 48 -h and 72-h timepoints $\left(\mathrm{R}_{\mathrm{ANOSIM}}<0.083\right)$ and between the two rootstock genotypes $\left(\mathrm{R}_{\text {ANOSIM }}<-0.074\right)$. At 7 days, however, the bacterial community was highly dissimilar from that detected at the previous sampling periods, but dissimilarity was greater for G.210 ( $\left.\mathrm{R}_{\text {ANOSIM }}>0.917\right)$ than M.26 ( $\left.\mathrm{R}_{\text {ANOSIM }}>0.444\right)$ rootstock (Figure 4). Comparable trends were observed in the SM-amended soil for M.26 rootstock; bacterial community composition was similar at $48 \mathrm{~h}$ and $72 \mathrm{~h}$, but, at 7 days, the community was dissimilar from that detected at the previous samplings ( $R_{\text {ANOSIM }}=0.482$ to 0.741; Figure 5). For G.210, $\mathrm{root} / \mathrm{rhizosphere} \mathrm{bacterial} \mathrm{communities} \mathrm{in} \mathrm{SM-amended} \mathrm{soils} \mathrm{were} \mathrm{somewhat} \mathrm{dissimilar}$ between the 48 -h and 72 -h samples $\left(\mathrm{R}_{\mathrm{ANOSIM}}=0.371\right)$ and highly dissimilar from the community detected at 7 days $\left(R_{\text {ANOSIM }}=0.667\right.$ to 0.926 ; Figure 5$)$. 


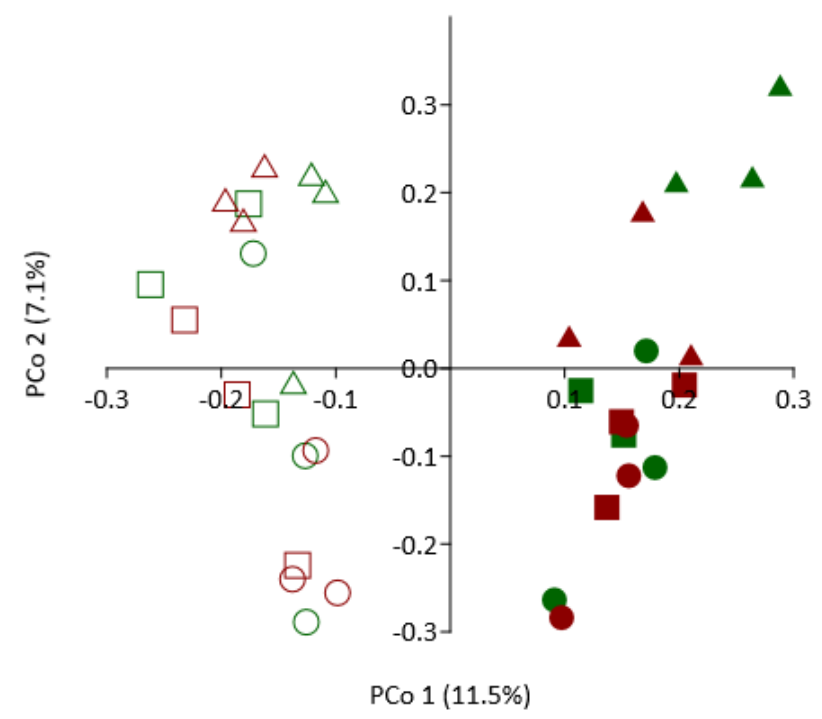

Figure 4. Influence of soil treatment on composition of the bacterial community detected in root/rhizosphere samples of tissue culture derived M.26 (dark red) and G.210 (green) rootstocks planted in non-treated (closed symbols) or SM-amended (open symbols) orchard replant soil. Principle coordinate analysis of operational taxonomic unit data was conducted using the Bray-Curtis dissimilarity coefficient. Symbols designate following timepoints: Circle $=48 \mathrm{~h}$; square $=72 \mathrm{~h}$; triangle $=7$ days; across all timepoints; soil treatment seed meal versus control; $p=0.0001$; $\mathrm{R}_{\mathrm{ANOSIM}}=0.6729$.
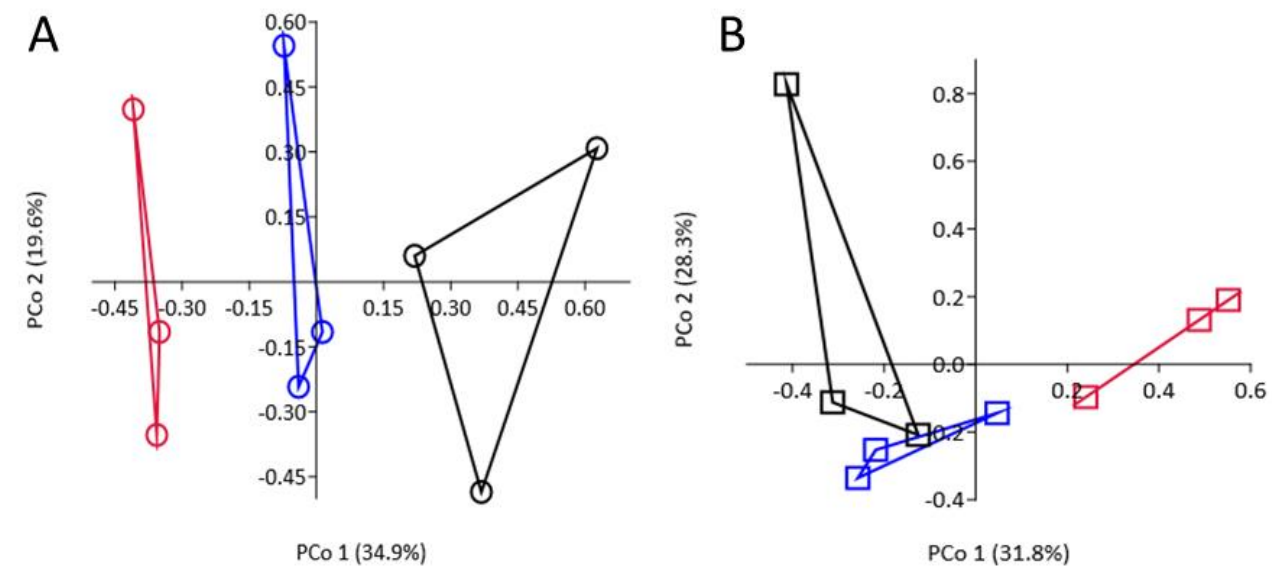

Figure 5. Relative changes in similarity of bacterial community composition over time in the rhizosphere off G.210 (A) and M.26 (B) apple rootstocks planted in SM (Brassica juncea/Sinapis alba; 1:1)-amended orchard soil. Principle coordinate analysis of operational taxonomic unit data was conducted using the Bray-Curtis dissimilarity coefficient. The convex hulls enclosing all data points for a given sampling timepoint. Black $=48 \mathrm{~h}$, Blue $=72 \mathrm{~h}$, and Red $=7$-day timepoints.

Among bacterial phyla, Actinobacteria exhibited the largest relative increase in the root/rhizosphere of both rootstocks in response to SM treatment. At the genus level, the $\mathrm{SM}$-induced increase of Actinobacteria as a proportion of the bacterial community corresponded with elevated abundance of Streptomyces spp., Arthrobacter spp., Nocardioides spp., and Rhodococcus spp. In particular, the relative proportion of Streptomyces spp. increased from less than $0.02 \%$ of the community to approximately $0.30 \%$ of the community in the rhizosphere of both rootstock genotypes. The number of bacterial species that were present at significantly greater abundance in the SM treatment than in the NTC increased from seven (belonging to 2 phyla) at $48 \mathrm{~h}$ to 37 (belonging to 5 phyla) at 7 days post-planting. The species demonstrating elevated relative abundance in SM treatment primarily belonged to the phyla Actinobacteria, Bacteroidetes, Chloroflexi, Firmicutes, Planctomycetes, 
and Proteobacteria, and mainly were reported to be involved in nutrient cycling or metabolizing potentially toxic organic compounds. For both rootstocks, multiple bacteria involved in nitrogen cycling, including Devosia yakushimensis, Flexibacter canadensis, Rhizobium loessense, Sinorhizobium spp., and Devosia spp., represented a greater proportion of the root/rhizosphere bacterial community recovered from SM-amended than the NTC soil. Bacteria known to function in suppression of various soil-borne plant pathogens, including members of the genera Lysobacter, Chitinophaga, Bacillus, and Paenibacillus, represented a significantly greater proportion of the community from both rootstocks when cultivated in SM-treated soil. Pantoea agglomerans comprised a significantly $(p=0.004)$ larger proportion of the bacterial community from M.26 than G.210 rootstock in the SM-treated soil.

\subsection{Differential Gene Expression between Rootstocks in Non-Treated Control Soil}

Differential gene expression between G.210 and M.26 rootstocks was investigated at each timepoint when plants were cultivated in NTC orchard replant soil. A total of 3769, 3202, and 3386 DEG were identified ( $p<0.01$ ) between M.26 and G.210 at 48, 72, and 7 days post-planting into NTC soil, respectively. Thus, rootstock transcriptomes were most divergent from each other at 48 h; at this time, 1823 (M.26) and 1946 (G.210) DEG were upregulated. The number of differentially expressed genes with higher expression levels was always greater in G.210 versus M.26 (48 h: $1946_{\mathrm{G} .210}, 1823_{\text {M.26 }} ; 72$ h: $1691_{\mathrm{G} .210}$, $1511_{\text {M.26 }} ;$ days: $1909_{\text {G.210, }}$ 1477 M.26).

Functional analysis of over-represented GO-terms indicated that at $48 \mathrm{~h}$ post-planting, several biological processes related to defense were elevated in M.26 relative to G.210 (Supplementary Materials Table S2), including, wounding response, defense response to bacterium, defense response to fungi, and sphingolipid metabolic process. Other GO terms associated with genotype-specific differences in cell wall integrity which were "upregulated" in M.26 included 1-3-beta-D-glucan biosynthetic processes, catabolism of polysaccharides and L-phenylalanine, tyrosine metabolism, and lipid metabolic/biosynthetic processes. L-phenalylalanine catabolism and lipid metabolic/biosynthetic processes may also be associated with reprogramming the transcriptome towards secondary metabolite production.

Over-represented GO terms (Supplementary Materials Tables S2 and S3) were assigned to 6 broad categories: cell wall integrity, defense, secondary metabolite biosynthesis, signaling/cellular regulation, biomass production, and carbon/energy use. PCA was then used to visualize the information contained in the enriched GO terms according to genotype and time (Figure 6). The samples show the largest amount of variation along PC1 ( 70\%), indicating that a greater amount of variance in the data set is explained by genotype than by time. In addition, defense, cell wall integrity, and secondary metabolite biosynthesis were highly correlated with each other and negatively correlated with biomass production, as well as carbon/energy use.

At all three timepoints, DEG potentially involved in cellular glucan metabolic processes were overrepresented in G.210 relative to M.26. The majority of DEG assigned to this GO term were involved in cell wall synthesis processes and included (1) UDP-forming Alpha-1,4-glucan-protein synthases, (2) Cellulose synthase proteins, and (3) Glycoside hydrolases family 16. Several UDP-glucose/GDP-mannose dehydrogenases were also expressed at higher levels at all timepoints in G.210. In plants, this enzyme is important for the synthesis of hemicellulose and pectin, which are the components of newly formed cell walls (InterPro v.73). This may be related to a need to synthesize biomass components for rapidly dividing root cells. Other aspects of new biomass production that were higher in G.210 relative to M.26 included genes involved in protein synthesis and DNA replication. At the same time, genes involved in protein ubiquitination (degradation) and translesion synthesis (DNA repair) were significantly upregulated in M.26 relative to G.210. 


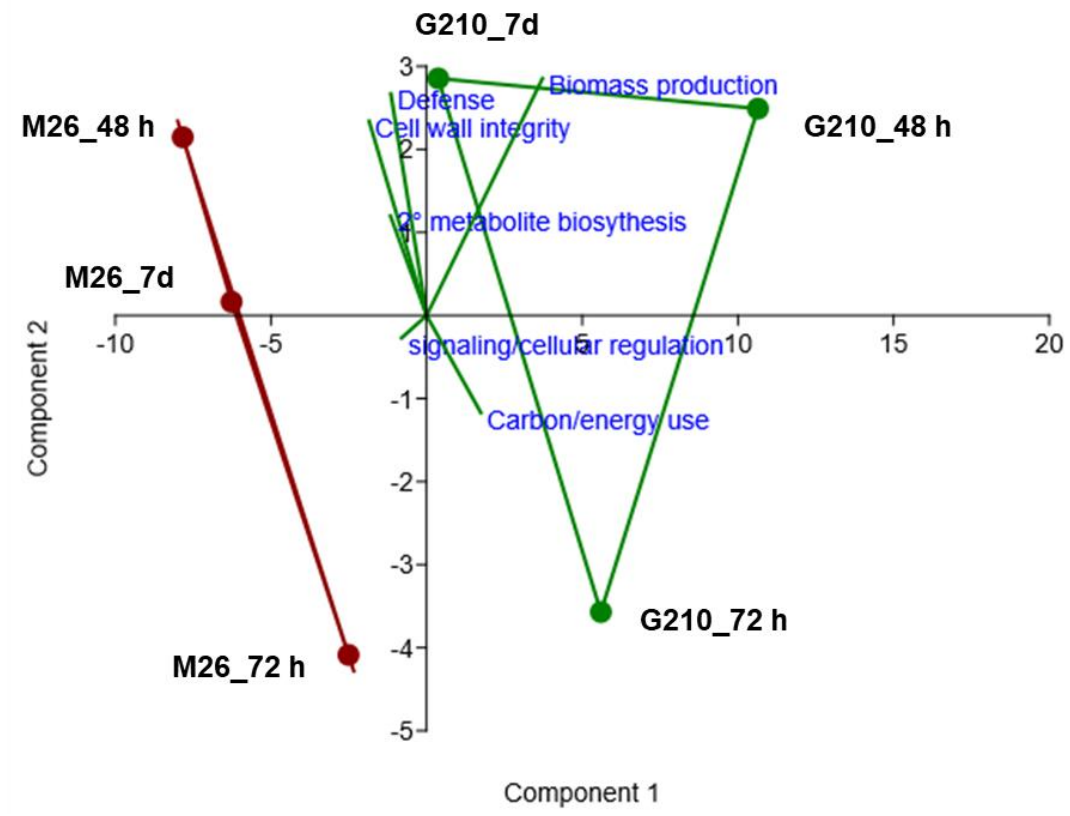

Figure 6. Principal components analysis of over-represented GO-terms terms in M.26 or G.210 rootstock at $48 \mathrm{~h}, 72 \mathrm{~h}$, and 7 days post-planting into non-treated orchard replant soil ( $p$-values derived from topGO gene enrichment analysis). For each genotype $\mathrm{x}$ time combination, significantly enriched GO-terms were tallied according to their predicted involvement in the following roles: defense, cell wall integrity, secondary metabolite production, signaling/cellular recognition, biomass production, and carbon/energy use. Only GO-terms with a $p$-value $<0.05$ and a False Discovery Rate (FDR) of $<1 \%$ were counted. This data was then used as input for the PCA. Convex hulls are shown for each genotype; G.210 (green), M26 (dark red).

At both 48 and $72 \mathrm{~h}$, there was strong evidence of differential transcriptional programming between the two genotypes in regards to carbon/energy use. The TCA cycle, gluconeogenesis, glycolysis, and acyl-CoA metabolic processes were initially "downregulated" in M.26 relative to G.210 (Figure 6, Supplementary Materials Table S3). Similarly, most of the enzymes involved in the conventional TCA cycle were identified as being downregulated in M.26 relative to G.210, including isocitrate dehydrogenase, oxoglutarate/iron-dependent oxygenase, fumarate lyase, malate dehydrogenase, and malic oxidoreductase. By $72 \mathrm{~h}$ post-planting, additional biological processes related to carbon/energy use partitioning became elevated in G.210 relative to M.26: NAD biosynthesis, the pentose-phosphate shunt, and glutamate and glutamine biosynthesis. During this timepoint $(72 \mathrm{~h})$, specific signaling-related processes (signal transduction, protein farnesylation, and protein homooligomerization) also became elevated in G.210 relative to M.26. Protein farnesylation has been shown to play a specific role in plant defense signaling [59].

As stated above, several biological processes related to defense were elevated in M.26 relative to G.210 $48 \mathrm{~h}$ post-planting in the NTC soil. In contrast, by 7 days, many GO terms related to defense were enriched in G.210 relative to M.26, including defense response, response to biotic stimulus, chitin catabolic processes, and peroxisome fission. Figure 6 reflects these transcriptional changes, as G.210 $\times 7$ days is positioned more closely to the top right quadrant of the plot. This result suggests that G.210 began directing resources towards additional defense mechanisms, including secondary metabolite biosynthesis, at a later time than M.26 in NTC soil.

\section{Discussion}

\subsection{Rootstock Transcriptome Responses in SM Treated Soil}

Soil-borne disease control in response to Brassicaceae SM soil amendment is attained through various biological and chemical functional pathways $[6,12,60]$. In this study, it was 
hypothesized that genes functional in pathogen defense and hormone signaling would be altered in response to SM application relative to the unamended control soil. Changes in the root transcriptome in response to these soil treatments were examined to assess the potential role of host genotype in modulating the disease control outcome. In addition, we hypothesized that alterations in host gene expression would be correlated with qualitative and/or quantitative changes in the rhizosphere-microbiome.

Upon pathogen infection, a number of integrated plant defense responses are typically activated to ward off the invader, including cell wall strengthening through synthesis of callose and lignin, pathogen cell wall degradation through synthesis of chitinases, glucanases, or pectinase, and accumulation of defense signaling components, such as pathogenesis related proteins [61-64]. Changes in plant hormone concentration and sensitivity can be triggered by biotic or abiotic stress conditions and subsequently mediate a wide range of adaptive responses [65]. Recent advances in characterization of plant immunity support the importance of phytohormones as primary signals in the regulation of plant defense responses $[65,66]$. In most cases, SA, JA, and ET interact antagonistically or synergistically as the backbone of the defense signaling network [67-73]. We find support for the hypothesis that phytohormone signaling and pathogen defense responses are not only treatment-dependent, but they are also largely genotype-dependent.

Expression patterns of genes in SM-amended soil and NTC soil were similar $48 \mathrm{~h}$ post-planting, regardless of rootstock genotype. However, by $72 \mathrm{~h}$ post-planting, there were distinctive transcriptional changes associated with cultivation in SM-amended soil and evidence of SM-mediated regulation of plant defense responses in both rootstock genotypes. For example, DEG involved in modulating phytohormone signaling pathways (e.g., auxin signaling and flavonoid biosynthesis in both genotypes; ET-mediated signaling in M.26; ABA-mediated signaling and suppression of JA signaling in G.210) and inducible defense responses (e.g., plant-pathogen interactions in both genotypes; chitin-induced immunity in M.26) had accumulated to higher levels in root tissue cultivated in SMamended soil relative to the NTC. In contrast, defense responses in G.210 were elevated in NTC treatments relative to SM treatments at the 7-day timepoint. For example, log2 fold change values for defense-associated DEG expressed in the roots of plants grown in SM-amended soil generally ranged from 2-5 (Table 4 and Figure 2C). For G.210 cultivated in NTC soil, several DEG involved in phytohormone signaling and defense had log2 fold change values much greater than 5 by 72 h (e.g., MDP0000166337, MDP0000296675, and MDP0000729108) and 7 days (e.g., MDP0000193383, MDP0000313454, and MDP0000206106) (Table 4 and Figure 2C). The shift toward a stronger defense response at the 7-day timepoint in G.210 x NTC was also evident based upon a comparison of gene expression profiles of G.210 and M.26 rootstocks cultivated in NTC soil (Figure 6).

Plants are programmed to minimize expression of resistance mechanisms in the absence of a stress event [74]. Inducible defenses have evolved to save energy under enemy-free conditions and plants express these defenses if the benefits outweigh the costs of the resistance response [75]. Priming for defense may enhance the plants potential to successfully protect against pathogen invasion at minimal cost to plant production. In the absence of pathogen infection, the energy cost of chemical defense priming by exposure to low doses of $\beta$-aminobutyric acid only resulted in minor reductions in relative growth rate for Arabidopsis [75]. The relatively small amount of defense gene expression triggered by SM amendment may lead to more rapid activation (priming) of defense reactions if the plant host is subjected to pathogen challenge.

A small number of DEG [32] were altered in a similar manner at the same timepoint in both rootstock genotypes when cultivated in SM-amended soil. This finding indicated that SM soil amendment specifically induced small changes to the transcriptome relative to that of the same rootstock when planted in NTC soil. A study on hyperosmotic priming of Arabidopsis seedlings showed that a mild salt treatment resulted in only minor changes in histone levels but significantly altered the epigenome landscape [76], suggesting that environmental fluctuations may lead to small changes in gene expression but significant 
changes in phenotype. This unique subset of DEG detected for rootstocks cultivated in SM-amended soil contained upregulated genes involved in disease resistance, as well as genes which may be associated with a broad range of other activities taking place in the plant in response to this treatment (e.g., metal ion binding, response to stresses, and lipid transfer).

Our analysis provided evidence that ethylene-mediated transcription factors are likely to be important aspects of the multicomponent defense strategy in both rootstock genotypes when exposed to pathogen attack, irrespective of the soil treatment. Transcription factors (TF) play an essential role in gene regulation and link phytohormone signaling with downstream metabolic pathways generating antimicrobial compounds and PR proteins [20]. Although differing in time and the specific gene, DEG encoding putative ethylene response factors (ERF-RAP2-4) were elevated in both soil treatments, regardless of genotype (ERF-RAP2-4: M.26 x SM-72 h; ERF-RAP2-4: G.210 x SM-7 day; ERF 2: M.26 x NTC-72 h; ERF-RAP2-11: G.210 x NTC-72 h).

The question remains as to the means by which defense priming is triggered by SM, given that root infection by soil-borne pathogens was shown in this and previous studies to be suppressed by Brassicaceae SM [8,12,77-79]. In both rootstock genotypes, a higher number of DEG downregulated in SM treatment were involved in antioxidant defense and cell wall-related processes reflecting a reduction in pathogen infection and corresponding cellular damage in SM treatments. This outcome would be anticipated based upon reduced pathogen loads commonly realized in response to SM amendment, which was observed in this and previous studies [12,19]. Both genotypes also showed reduced transcription of MLO proteins at $72 \mathrm{~h}$ in SM (relative to NTC), a change which has been associated with reduced susceptibility to oomycete pathogens [80].

\subsection{Transformation of the Rhizosphere Microbiome}

Plant defense responses can be induced by several elements, including perception of pathogens [81], insect herbivores [82,83], chemical compounds [84-86], and plant beneficial microorganisms [87]. Therefore, an additional aim of this study was to explore whether alterations in host gene expression were temporally associated with changes in density and/or community composition of the rhizosphere-microbiome.

Transformation of the rhizosphere microbiome is critical for long-term pathogen suppression obtained in response to Brassicaceae SM amendment $[8,12,78,88]$. Specific changes in structure of the rhizosphere microbiome in response to SM function in control of various apple root pathogens with the microbial group(s) contributing to disease control often differing with the target pathogen [5,8]. It was previously proposed that amplification of Streptomyces apple rhizosphere populations in SM-amended soil contributed to the suppression of root infection by R. solani AG- 5 via induction of host systemic resistance response [6,8]. Similarly, in the current study, relative abundance of Streptomyces was significantly amplified in the rhizosphere of SM-cultivated rootstocks in association with altered gene expression and disease control. The modified microbiome possessed several additional elements associated with suppression of soil-borne pathogens, nutrient cycling or degradation of recalcitrant chemical compounds. These included bacteria involved in nitrogen fixation, such as Sinorhizobium spp., pathogen suppression, such as Lysobacter spp. [89,90], and soil bioremediation, such as Shinella spp. [91] and Arthrobacter spp. [92].

After 7 days, M.26 cultivated in the NTC soil supported greater levels of fungi in the root zone than those cultivated in the SM-amended soil. Interestingly, SM was associated with a heightened level of fungal defense (Chitin catabolic process) in M.26 (but not in G.210) at $72 \mathrm{~h}$. Thus, fungal pathogens may have more rapidly colonized susceptible M.26 roots in NTC soil and accumulated to higher levels in the root zone. The ARD susceptible rootstock M.26 grown in NTC soil has consistently been found to support higher fungal loads than the tolerant rootstock G.210 [9] and a greater relative abundance of fungi that function as root pathogens of apple, including Ilyonectria robusta $[9,25,93]$. In the current study, G.210 cultivated in SM-amended soil supported a greater density of fungi in root 
zones than in the NTC soil after 7 days. SM-associated rhizosphere fungal communities generally consist of a greater number of taxa with positive plant associations than the community in a corresponding untreated soil $[9,12,19]$. There is also evidence that Geneva rootstocks generally host higher levels of arbuscular mycorrhizal fungi (AMF), as compared to rootstocks in the Malling series [93]. AMF rely on carbon compounds derived from host plant photosynthesis and may play a role in displacing pathogenic fungi. As stated above, upregulated DEG in G.210 at $72 \mathrm{~h}$ mapped to KEGG pathways associated with starch and sucrose metabolism, Glycolysis/gluconeogenesis, and Galactose metabolism (Figure 3). It is also notable that 2 DEG associated with Carotenoid biosynthesis were upregulated at $72 \mathrm{~h}$ in G.210 (Table 4 and Figure 3). Carotenoid derived strigolactones have been implicated in presymbiotic signaling to AMF root colonization [94].

Unlike fungi, the quantity of bacterial DNA detected in the root zone did not appear to be treatment-dependent, suggesting that SM-mediated protection in the rhizosphere may have more to do with the changes in bacterial community composition noted above than density. There was, however, some evidence that transcriptional responses may have affected bacterial abundance in the rhizosphere of M.26. The large reduction in bacterial abundance which occurred in both NTC and SM treatments between $72 \mathrm{~h}$ and 7 days coincided with specific transcriptomic changes associated with the metabolism of sugars (M.26 x NTC), carbohydrates (M.26 x NTC), and amino acids (M.26 x NTC and SM), materials which are typically released in large quantities in root exudates (Figure 3A). Thus, the observed reduction in bacterial density at the 7-day timepoint both M.26 treatments may have been related to the reallocation of photosynthate toward defense-related activities (e.g., secondary metabolite production).

\subsection{Genotype-Specific Transcriptome Response to Cultivation in NTC Replant Orchard Soil}

Differential gene expression between the tolerant and susceptible rootstock in NTC soil revealed a number of defense-related changes occurring under pathogen pressure and provided insight into genotype-specific mechanisms of resistance. For example, genes linked to changes in cell wall integrity and the wounding response supported the hypothesis that M.26 was experiencing higher initial levels of cellular injury than G.210. At the same time, genes involved in cell wall organization and biogenesis were more highly expressed in G.210, a finding which may be related to the need to synthesize biomass components for rapidly dividing root cells.

Zhu et al. [24] demonstrated that, in the absence of pathogen challenge, the disease tolerant apple rootstock, G.935, possessed elevated transcript abundance for genes annotated to system-wide defense responses in root tissue relative to that detected in the disease susceptible rootstock B.9. When challenged with the root pathogen Pythium ultimum, transcript profiles for four specific defense related genes exhibited early (day 1) but transient induction in the susceptible rootstock [23]. In contrast, induction levels for these genes was higher in G.935 and persisted at later timepoints, including 7 and 14 days. Therefore, in addition to modulation of root architecture, we hypothesized that genotype-specific changes related to more rapid defense induction would be evident in G.210. In this case, when cultivated in NTC soil, we did not see clear evidence for more rapid defense induction by G.210 relative to M.26 at the 48- or 72-h timepoints. Biological processes related to defense (including increased expression of genes involved in hypersensitive responses) were not elevated in G.210 relative to M.26 until the 7-day timepoint, which is similar to the previous findings of Zhu et al. [23,24]. Likewise, in a transcriptome study on grapevine resistance to powdery mildew, the authors found evidence for strong induction of the basal defense response in the susceptible genotype, while the transcriptome of the resistant genotype responded weakly to powdery mildew infection [95]. In contrast, there was little evidence that G.210 was redirecting resources towards basal defense mechanisms at this later timepoint in SM-amended soil. Along these same lines, by 7 days, NTC and SM-amended transcriptomes had largely diverged in G.210, and there was a large accumulation of genes related to defense which were expressed at higher levels in the NTC relative 
to SM-amended soil (i.e., downregulated). However, in M.26, NTC and SM-amended transcriptomes were largely identical at 7 days. This was surprising considering that by $72 \mathrm{~h}$, a number of DEG involved in phytohormone signaling and/or the utilization of secondary metabolites had accumulated to higher levels in M.26 root tissue cultivated in NTC, in comparison to SM-amended soil. However, the transient nature of the response in the susceptible rootstock is in concordance with findings that were observed when the susceptible B.9 rootstock was challenged with P. ultimum [23].

\section{Conclusions}

This study demonstrates the significant effect of an organic plant residue soil amendment on the apple root transcriptome and on rhizosphere microbial community dynamics. The results of this study support the hypothesis that both apple rootstock genotypes benefitted from the SM soil amendment in multiple manners, including: SM-mediated defense responses, prophylactic alterations to the root-associated microbiome, and reduced pathogen loads in comparison to the NTC. More specifically, these findings suggest that SM-dependent transcriptional changes may protect plants by priming them for improved performance during subsequent (and more intensive) pathogen-induced cellular defense responses. However, further studies are necessary to improve our understanding of exactly how SM influences plant defense mechanisms in different apple rootstock genotypes. The patterns revealed by differential gene expression analysis also provided new insight into how ARD "susceptible" versus "tolerant" rootstock cultivars may differ in their response to pathogen pressure. Genotype-specific trade-offs in energy allocation largely influenced the timing of induced defense responses in NTC soil. We propose that, upon exposure to ARD-pathogens, G.210 initially allocates more energy to the production of new root biomass, while M.26 directs resources towards defense and secondary metabolite production. Overall, findings from this study will be of value for rootstock breeding through identification of genes that may confer host tolerance/resistance and optimization of implementation strategies for alternative soil-borne disease management programs that do not utilize pre-plant soil fumigation.

Supplementary Materials: The following are available online at https:/ /www.mdpi.com/article/ 10.3390/microorganisms 9040763 /s1, Figure S1: Validation of differential expression patterns for selected differentially expressed genes in apple rootstock G.210 by qRT-PCR, Figure S2: Validation of differential expression patterns for selected differentially expressed genes in apple rootstock M.26 by qRT-PCR, Table S1: Statistics of RNA-seq read mapping, Table S2: Significant GO Biological Process terms $(p<0.05)$ over-represented in M.26 relative to G.210, Table S3: Significant GO Biological Process terms $(p<0.05)$ over-represented in G.210 relative to M.26.

Author Contributions: Conceptualization, M.M., L.W., T.S.S.; methodology, M.M., L.W., T.S.S., formal analysis, L.W., T.S.S., H.H., L.H., M.M.; investigation, L.W., T.S.S., M.M.; data curation, T.S.S., H.H., L.H.; writing—original draft preparation, L.W., M.M., T.S.S.; writing—review and editing, M.M., T.S.S., L.H.; visualization, L.W., M.M., T.S.S.; project administration, M.M.; funding acquisition, M.M. All authors have read and agreed to the published version of the manuscript.

Funding: This work was supported in part through funding from the National Institute of Food and Agriculture, U.S. Department of Agriculture provided to M.M. under award number 2012-5110220294 and 2016-51102-25815.

Institutional Review Board Statement: Not applicable.

Informed Consent Statement: Not applicable.

Data Availability Statement: The datasets generated and analyzed during the current study are available in the Figshare repository (10.6084/m9.figshare.14219483) and include unedited 16 S rRNA OTU read count tables, as well as non-normalized raw counts of the sequencing reads, which were used for the differential expression analysis. Any other data generated or analyzed during this study are included in this published article and its supplementary information files or are available from the corresponding author upon reasonable request. 
Conflicts of Interest: The authors declare no conflict of interest.

\section{References}

1. Matthiessen, J.; Kirkegaard, J. Biofumigation and Enhanced Biodegradation: Opportunity and Challenge in Soilborne Pest and Disease Management. Crit. Rev. Plant Sci. 2006, 25, 235-265. [CrossRef]

2. Kirkegaard, J.A.; Gardiner, P.A.; Desmarchelier, J.M.; Angus, J.F. Biofumigation using Brassica species to control pests and diseases in horticulture and agriculture. In Proceedings 9th Australian Research Assembly on Brassicas; Wratten, N., Mailer, R.J., Eds.; Wagga Wagga Agricultural Research Institute: Wagga Wagga, New South Wales, Australia, 1993; pp. 77-82.

3. Ntalli, N.; Caboni, P. A review of isothiocyanates biofumigation activity on plant parasitic nematodes. Phytochem. Rev. 2017, 16, 827-834. [CrossRef]

4. Brennan, R.J.B.; Glaze-Corcoran, S.; Wick, R.; Hashemi, M. Biofumigation: An alternative strategy for the control of plant parasistic nematodes. J. Integr. Agric. 2020, 19, 1680-1690. [CrossRef]

5. Weerakoon, M.D.; Reardon, C.L.; Paulitz, T.C.; Izzo, A.D.; Mazzola, M. Long-term suppression of Pythium abappressorium induced by Brassica juncea seed meal amendment is biologically mediated. Soil Biol. Biochem. 2012, 51, 44-52. [CrossRef]

6. Cohen, M.F.; Yamasaki, H.; Mazzola, M. Brassica napus seed meal soil amendment modifies microbial community structure, nitric oxide production and incidence of Rhizoctonia root rot. Soil Biol. Biochem. 2005, 37, 1215-1227. [CrossRef]

7. Mazzola, M.; Granatstein, D.M.; Elfving, D.C.; Mullinix, K. Suppression of specific apple root pathogens by Brassica napus seed meal amendment regardless of glucosinolate content. Phytopathology 2001, 91, 673-679. [CrossRef] [PubMed]

8. Cohen, M.F.; Mazzola, M. Impact of resident bacteria, nitric oxide emission and particle size on root infection by Pythium spp. and R. solani AG-5 in Brassica napus seed meal amended soils. Plant Soil 2006, 286, 75-86. [CrossRef]

9. Somera, T.S.; Freilich, S.; Mazzola, M. Comprehensive analysis of the apple rhizobiome as influenced by different Brassica seed meal and rootstocks in the same soil/plant system. Appl. Soil Ecol. 2021. [CrossRef]

10. Bastian, F.; Bouziri, L.; Nicolardot, B.; Ranjard, L. Impact of wheat straw decomposition on successional patterns of soil microbial community structure. Soil Biol. Biochem. 2009, 41, 262-275. [CrossRef]

11. Blaud, A.; Diouf, F.; Herrmann, A.M.; Lerch, T.Z. Analyzing the effect of soil organic matter on bacterial communities using T-RFLP fingerprinting: Different methods, different stories? Biol. Fert. Soils 2015, 51, 959-971. [CrossRef]

12. Mazzola, M.; Hewavitharana, S.; Strauss, S.L. Brassica seed meal soil amendments transform the rhizosphere microbiome and improve apple production through resistance to pathogen reinfestation. Phytopathology 2015, 105, 460-467. [CrossRef]

13. Ventorino, V.; Parillo, R.; Testa, A.; Viscardi, S.; Espresso, F.; Pepe, O. Chestnut green waste composting for sustainable forest management: Microbiota dynamics and impact on plant disease control. J. Environ. Manag. 2015, 166, 168-177. [CrossRef] [PubMed]

14. Berendsen, R.L.; Pieterse, C.M.J.; Bakker, P.A.H.M. The rhizosphere microbiome and plant health. Trends Plant Sci. 2012, 17, 478-486. [CrossRef] [PubMed]

15. Hol, W.H.G.; De Boer, W.; Termorshuizen, A.J.; Meyer, K.M.; Schneider, J.H.M.; Van Dam, N.M.; van Veen, J.A.; van der Putten, W.H. Reduction of rare soil microbes modifies plant herbivore interactions. Ecol. Lett. 2010, 13, 292-301. [CrossRef]

16. Martinuz, A.; Schouten, A.; Menjivar, R.D.; Sikora, R.A. Effectiveness of systemic resistance toward Aphis gossypii (Hom., Aphididae) as induced by combined applications of the endophytes Fusarium oxysporum Fo162 and Rhizobiumetli G12. Biol. Control 2012, 62, 206-212. [CrossRef]

17. Mendes, R.; Kruijt, M.; de Bruijin, I.; Dekkers, E.; van der Voort, M.; Schneider, J.H.M.; Piceno, Y.M.; DeSantis, T.Z.; Andersen, G.L.; Bakker, P.A.H.M.; et al. Deciphering the rhizosphere microbiome for disease suppressive bacteria. Science 2011, 332, 1097-1100. [CrossRef]

18. Partida-Martinez, L.P.; Heil, M. The microbe-free plant: Fact or artifact? Front. Plant Sci. 2011, 2, 100. [CrossRef]

19. Wang, L.; Mazzola, M. Field evaluation of reduced rate Brassicaceae seed meal amendment and rootstock genotype on the microbiome and control of apple replant disease. Phytopathology 2019, 109, 1378-1391. [CrossRef]

20. Shin, S.; Zheng, P.; Fazio, G.; Mazzola, M.; Main, D.; Zhu, Y. Transcriptome changes specially associated with apple (Malus domestica) root defense response during Pythium ultimum infection. Physiol. Mol. Plant Pathol. 2016, 94, 16-26. [CrossRef]

21. Ruzicka, D.R.; Barrios-Masias, F.H.; Hausmann, N.T.; Jackson, L.E.; Schachtman, D.P. Tomato root transcriptome response to a nitrogen-enriched soil patch. BMC Plant Biol. 2010, 10, 75. [CrossRef]

22. Viger, M.; Hancock, R.D.; Miglietta, F.; Taylor, G. More plant growth but less plant defence? First global gene expression data for plants grown in soil amendment with biochar. GCB Bioenergy 2015, 7, 658-672. [CrossRef]

23. Zhu, Y.; Shin, S.; Mazzola, M. Genotype responses of two apple rootstocks to infection by Pythium ultimum causing apple replant disease. Can. J. Plant Pathol. 2016, 38, 483-491. [CrossRef]

24. Zhu, Y.; Shao, J.; Zhou, Z.; Davis, R.E. Comparative transcriptome analysis reveals a performed defense system in apple root of a resistant genotype of G.935 in the absence of pathogen. Int. J. Plant Genom. 2017, 8950746. [CrossRef]

25. Emmett, B.; Nelson, E.B.; Kessler, A.; Bauerle, T. Fine-root system development and susceptibility to pathogen colonization. Planta 2014, 239, 325-340. [CrossRef]

26. Atucha, A.; Emmett, B.; Bauerle, T.L. Growth rate of fine root systems influences rootstock tolerance to replant disease. Plant Soil 2014, 376, 337-346. [CrossRef] 
27. Mazzola, M. Elucidation of the microbial complex having a causal role in the development of apple replant disease in Washington. Phytopathology 1998, 88, 930-938. [CrossRef]

28. Hewavitharana, S.S.; Rudell, D.; Mazzola, M. Carbon source-dependent antifungal and nematicidal volatiles derived during anaerobic soil disinfestation. Eur. J. Plant Pathol. 2014, 140, 39-52. [CrossRef]

29. Brown, J.; Davis, J.B.; Erickson, D.A.; Gosselin, T.K. Registration of 'Pacific Gold' oriental condiment mustard. Crop. Sci. 2004, 44, 2271-2272. [CrossRef]

30. Brown, J.; Davis, J.B.; Erickson, D.A.; Brown, A.P.; Seip, L. Registration of 'IdaGold' mustard. Crop. Sci. 1997, $38,541$.

31. Yepes, L.M.; Aldwinckle, H.S. Micropropagation of thirteen Malus cultivars and rootstocks, and effect of antibiotics on proliferation. Plant Growth Regul. 1994, 15, 55-67. [CrossRef]

32. Gasic, K.; Hernandez, A.; Korban, S. RNA extraction from different apple tissues rich in polyphenols and polysaccharides for cDNA library construction. Plant Mol. Biol. Rep. 2004, 22, 437-438. [CrossRef]

33. Velasco, R.; Zharkikh, A.; Affourtit, J.; Dhingra, A.; Cestaro, A.; Kalyanaraman, A.; Fontana, P.; Bhatnagar, S.K.; Troggio, M.; Pruss, D.; et al. The genome of the domesticated apple (Malus $\times$ domestica Borkh). Nature Genet. 2010, 42, 833-839. [CrossRef] [PubMed]

34. Jung, S.; Lee, T.; Cheng, C.H.; Buble, K.; Zheng, P.; Yu, J.; Humann, J.; Ficklin, S.P.; Gasic, K.; Scott, K.; et al. 15 years of GDR: New data and functionality in the Genome Database for Rosaceae. Nucleic Acids Res. 2019, 47, D1137-D1145. [CrossRef]

35. Andrews, S.; Fast, Q.C. A Quality Control Tool for High Throughput Sequence Data. 2010. Available online: http://www. bioinformatics.babraham.ac.uk/projects/fastqc/ (accessed on 3 March 2021).

36. Robinson, M.D.; Smyth, G.K. Small-sample estimation of negative binomial dispersion, with applications to sage data. Biostatistics 2008, 9, 321-332. [CrossRef] [PubMed]

37. Camacho, C.; Madden, T.; Coulouris, G.; Avagyan, V.; Ma, N.; Tao, T.; Agarwala, R. BLAST Command Line Applications User Manual. Bethesda (MD): National Center for Biotechnology Information (US). 2008. Available online: http:/ /www.ncbi.nlm.nih. gov/books/NBK279674/ (accessed on 24 February 2021).

38. Conesa, A.; Madrigal, P.; Tarazona, S.; Gomez-Cabrero, D.; Cervera, A.; McPherson, A.; Wojciech Szcześniak, M.; Gaffney, D.J.; Elo, L.L.; Zhang, X.; et al. A survey of best practices for RNA-seq data analysis. Genome Biol. 2016, 17, 13. [CrossRef]

39. Love, M.I.; Huber, W.; Anders, S. Moderated estimation of fold change and dispersion for RNA-Seq data with DESeq2. Genome Biol. 2014, 15, 550. [CrossRef]

40. Alexa, A.; Rahnenfuhrer, J. Gene set enrichment analysis with topGO. In R Package Version 3.5.3; R Foundation for Statistical Computing: Vienna, Austria, 2007.

41. Livak, K.J.; Schmittgen, T.D. Analysis of relative gene expression data using real-time quantitative PCR and the 2(-Delta Delta C(T)) method. Methods 2001, 25, 402-408. [CrossRef]

42. Martin, K.; Rygiewicz, P.T. Fungal-specific PCR primers developed for analysis of the ITS region of environmental DNA extracts. BMC Microbiol. 2005, 5, 28. [CrossRef]

43. Vilgalys, R.; Hester, M. Rapid genetic identification and mapping of enzymatically amplified ribosomal DNA from several Cryptococcus species. J. Bacteriol. 1990, 172, 4238-4246. [CrossRef]

44. Øvreas, L.; Torsvik, V. Microbial diversity and community structure in two different agricultural soil communities. Microb. Ecol. 1998, 36, 303-315. [CrossRef]

45. Robertson, C.E.; Harris, J.K.; Wagner, B.D.; Granger, D.; Browne, K.; Tatem, B.; Feazel, L.M.; Park, K.; Pace, N.R.; Frank, D.N. Explicet: Graphical user interface software for metadata-driven management, analysis and visualization of microbiome data. Bioinformatics 2013, 29, 3100-3101. [CrossRef] [PubMed]

46. Wagner, B.D.; Roberson, C.E.; Harris, J.K. Application of two-part statistic for comparison of sequence variant counts. PLoS ONE 2011, 6, e20296. [CrossRef] [PubMed]

47. Kieber, J.J.; Rothenberg, M.; Roman, G.; Feldmann, K.A.; Ecker, J.R. CTR1, a negative regulator of the ethylene response pathway in Arabidopsis, encodes a member of the Raf family of protein kinases. Cell 1993, 72, 427-441. [CrossRef]

48. Shinya, T.; Yamaguchi, K.; Desaki, Y.; Yamada, K.; Narisawa, T.; Kobayashi, Y.; Maeda, K.; Suzuki, M.; Tanimoto, T.; Takeda, J.; et al. Selective regulation of the chitin-induced defense response by the Arabidopsis receptor-like cytoplasmic kinase PBL27. Plant J. 2014, 79, 56-66. [CrossRef]

49. Turner, J.G.; Ellis, C.; Devoto, A. The jasmonate signal pathway. Plant Cell 2002, 14, 153-164. [CrossRef]

50. Wang, K.L.-C.; Li, H.; Ecker, J.R. Ethylene biosynthesis and signaling networks. Plant Cell 2002, 14, 131-151. [CrossRef]

51. Devoto, A.; Turner, J.G. Regulation of jasmonate-mediated plant responses in Arabidopsis. Ann. Bot. 2003, 92, 329-337. [CrossRef]

52. Okubara, P.; Paulitz, T. Root defense responses to fungal pathogens: A molecular perspective. Plant Soil 2005, 274, 215-226. [CrossRef]

53. Pauwels, L.; Barbero, G.F.; Geerinck, J.; Tilleman, S.; Grunewald, W.; Pérez, A.C.; Chico, J.M.; Bossche, R.V.; Sewell, J.; Gil, E.; et al. NINJA connects the corepressor TOPLESS to jasmonate signaling. Nature 2010, 464, 788-791. [CrossRef]

54. Zeilmaker, T.; Ludwig, N.R.; Elberse, J.; Seidl, M.F.; Berke, L.; Van Doorn, A.; Schuurink, R.C.; Snel, B.; Van den Ackerveken, G. Downy mildew resistant 6 and DMR6-like oxygenase 1 are partially redundant but distinct suppressors of immunity in Arabidopsis. Plant J. 2015, 81, 210-222. [CrossRef]

55. De Geyter, N.; Gholami, A.; Goormachtig, S.; Goossens, A. Transcriptional machineries in jasmonate-elicited plant secondary metabolism. Trends Plant Sci. 2012, 17, 349-359. [CrossRef] [PubMed] 
56. Hartwig, U.A.; Maxwell, C.A.; Joseph, C.M.; Phillips, D.A. Chrysoeriol and luteolin released from alfalfa seeds induce nod genes in Rhizobium meliloti. Plant Physiol. 1990, 92, 116-122. [CrossRef] [PubMed]

57. Peer, W.A.; Murphy, A.S. Flavonoids and auxin transport: Modulators or regulators? Trends Plant Sci. 2007, 12, 556-563. [CrossRef]

58. Mierziak, J.; Kostyn, K.; Kulma, A. Flavonoids as important molecules of plant interactions with the environment. Molecules 2014, 19, 16240-16265. [CrossRef]

59. Goritschnig, S.; Weihmann, T.; Zhang, Y.; Fobert, P.; McCourt, P.; Li, X. A novel role for protein farnesylation in plant innate immunity. Plant Physiol. 2008, 148, 348-357. [CrossRef] [PubMed]

60. Mazzola, M.; Brown, J.; Zhao, X.; Izzo, A.D.; Fazio, G. Interaction of Brassicaceous seed meal and apple rootstock on recovery of Pythium spp. and Pratylenchus penetrans from roots grown in replant soils. Plant Dis. 2009, 93, 51-57. [CrossRef]

61. Göhre, V.; Robatzek, S. Breaking the barriers: Microbial effector molecules subvert plant immunity. Annu. Rev. Phytopathol. 2008, 46, 189-215. [CrossRef]

62. Schwessinger, B.; Zipfel, C. News from the frontline: Recent insights into PAMP-triggered immunity in plants. Curr. Opin. Plant Biol. 2008, 11, 389-395. [CrossRef] [PubMed]

63. Tsuda, K.; Sato, M.; Glazebrook, J.; Cohen, J.D.; Katagiri, F. Interplay between MAMP-triggered and SA-mediated defense responses. Plant J. 2008, 53, 763-775. [CrossRef]

64. Nürnberger, T.; Kemmerling, B. Pathogen-associated molecular patterns (PAMP) and PAMP-triggered immunity. Annu. Plant Rev. 2009, 34, 16-47.

65. Pieterse, C.M.J.; Leon-Reyes, A.; Van der Ent, S.; Van Wees, S.C.M. Networking by small-molecules hormones in plant immunity. Nat. Chem. Biol. 2009, 5, 308-316. [CrossRef] [PubMed]

66. Spoel, S.H.; Dong, X. Making sense of hormone crosstalk during plant immune responses. Cell Host Microbe 2008, 3, 348-351. [CrossRef] [PubMed]

67. Wang, D.; Pajerowska-Mukhtar, K.; Hendrickson Culler, A.; Dong, X. Salicylic acid inhibits pathogen growth in plants through repression of the auxin signaling pathway. Curr. Biol. 2007, 17, 1784-1790. [CrossRef] [PubMed]

68. Navarro, L.; Bari, R.; Achard, P.; Lison, P.; Nemri, A.; Harberd, N.P.; Jones, J.D.G. DELLAs control plant immune responses by modulating the balance of jasmonic acid and salicylic acid signaling. Curr. Biol. 2008, 18, 650-655. [CrossRef] [PubMed]

69. Yasuda, M.; Ishikawa, A.; Jikumaru, Y.; Seki, M.; Umezawa, T.; Asami, T.; Maruyama-Nakashita, A.; Kudo, T.; Shinozaki, K.; Yoshida, S.; et al. Antagonistic interaction between systemic acquired resistance and the abscisic acid-mediated abiotic stress response in Arabidopsis. Plant Cell 2008, 20, 1678-1692. [CrossRef]

70. Campos, M.L.; de Almeida, M.; Rossi, M.L.; Martinelli, A.P.; Litholdo, C.G.; Figueira, A.; Rampelotti-Ferreira, F.T.; Vendramim, J.D.; Benedito, V.A.; Peres, L.E.P. Brassinosteroids interact negatively with jasmonates in the formation of anti-herbivory traits in tomato. J. Exp. Bot. 2009, 60, 4346-4360. [CrossRef] [PubMed]

71. de Torres-Zabala, M.; Bennett, M.H.; Truman, W.H.; Grant, M.R. Antagonism between salicylic and abscisic acid reflects early host-pathogen conflict and moulds plant defence responses. Plant J. 2009, 59, 375-386. [CrossRef]

72. De Vleesschauwer, D.; Yang, Y.; Cruz, C.V.; Höfte, M. Abscisic acid-induced resistance against the brown spot pathogen Cochliobolus miyabeanus in rice involves MAP kinase-mediated repression of ethylene signaling. Plant Physiol. 2010, 152, $2036-2052$. [CrossRef]

73. Jiang, C.J.; Shimono, M.; Sugano, S.; Kojima, M.; Yazawa, K.; Yoshida, R.; Inoue, H.; Hayashi, N.; Sakakibara, H.; Takatsuji, H. Abscisic acid interacts antagonistically with salicylic acid signaling pathway in rice-Magnaporthe grisea interaction. Mol. Plant Microbe Interact. 2010, 23, 791-798. [CrossRef]

74. Tian, D.; Traw, M.B.; Chen, J.Q.; Kreitman, M.; Bergelson, J. Fitness costs of R-gene-mediated resistance in Arabidopsis thaliana. Nature 2003, 423, 74-77. [CrossRef]

75. Van Hulten, M.; Pelser, M.; van Loon, L.C.; Pieterse, C.M.J.; Ton, J. Costs and benefits of priming for defense in Arabidopsis. Proc. Natl. Acad. Sci. USA 2006, 103, 5602-5607. [CrossRef]

76. Sani, E.; Herzyk, P.; Perrella, G.; Colot, V.; Amtmann, A. Hyperosmotic priming of Arabidopsis seedlings establishes a long-term somatic memory accompanied by specific changes of the epigenome. Genome Biol. 2013, 14, R59. [CrossRef]

77. Mazzola, M.; Brown, J. Efficacy of Brassicaceous seed meal formulations for the control of apple replant disease in organic and conventional orchard production systems. Plant Dis. 2010, 94, 835-842. [CrossRef] [PubMed]

78. Mazzola, M.; Zhao, X. Brassica juncea seed meal particle size influences chemistry but not soil biology-based suppression of individual agents inciting apple replant disease. Plant Soil 2010, 337, 313-324. [CrossRef]

79. Mazzola, M.; Manici, L.M. Apple replant disease: Role of microbial ecology in cause and control. Annu. Rev. Phytopathol. 2012, 50, 45-65. [CrossRef] [PubMed]

80. Kim, D.S.; Hwang, B.K. The pepper MLO gene, CaMLO2, is involved in the susceptibility cell-death response and bacterial and oomycete proliferation. Plant J. 2012, 72, 843-855. [CrossRef] [PubMed]

81. Newman, M.A.; von Roepenack-Lahaye, E.; Parr, A.; Daniels, M.J.; Dow, J.M. Prior exposure to lipopolysaccharide potentiates expression of plant defenses in response to bacteria. Plant J. 2002, 29, 487-495. [CrossRef]

82. Conrath, U.; Becker, G.J.; Langenbach, C.J.; Jaskiewicz, M.R. Priming for enhanced defense. Annu. Rev. Phytopathol. 2015, 53, 97-119. [CrossRef] 
83. Hilker, M.; Schwachtje, J.; Baier, M.; Balazadeh, S.; Bäurle, I.; Geiselhardt, S.; Hincha, D.K.; Kunze, R.; Mueller-Roeber, B.; Rillig, M.C.; et al. Priming and memory of stress responses in organisms lacking a nervous system. Biol. Rev. 2015, 4, 1118-1133. [CrossRef]

84. Oostendorp, M.; Kunz, W.; Dietrich, B.; Staub, T. Induced disease resistance in plants by chemicals. Eur. J. Plant Pathol. 2001, 107, 19-28. [CrossRef]

85. Pastor, V.; Luna, E.; Mauch-Mani, B.; Ton, J.; Flors, V. Primed plants do not forget. Environ. Exp. Bot. 2012, 94, 46-56. [CrossRef]

86. Balmer, A.; Pastor, V.; Gamir, J.; Flors, V.; Mauch-Mani, B. The 'prime-ome': Towards a holistic approach to priming. Trends Plant Sci. 2015, 20, 443-452. [CrossRef] [PubMed]

87. Pieterse, C.M.J.; Zamioudis, C.; Berendsen, R.J.; Weller, D.M.; Van Wees, S.C.M.; Bakker, P.A.H.M. Induced systemic resistance by beneficial microbes. Annu. Rev. Phytopathol. 2014, 52, 347-375. [CrossRef]

88. Galletti, S.; Sala, E.; Leoni, O.; Burzi, P.L.; Cerato, C. Trichoderma spp. tolerance to Brassica carinata seed meal for a combined use in biofumigation. Biol. Control 2008, 45, 319-327. [CrossRef]

89. Kobayashi, D.Y.; Reedy, R.M.; Palumbo, J.D.; Zhou, J.M.; Yuen, G.Y. A clp gene homologue belonging to the crp gene family globally regulates lytic enzyme production, antimicrobial activity, and biological control activity expressed by Lysobacter enzymogenes strain C3. Appl. Environ. Microbiol. 2005, 71, 261-269. [CrossRef] [PubMed]

90. Kobayashi, D.Y.; Yuen, G.Y. The role of clp-regulated factors in antagonism against Magnaporthe poae and biological control of summer patch disease of Kentucky bluegrass by Lysobacter enzymogenes C3. Can. J. Microbiol. 2005, 51, 719-723. [CrossRef] [PubMed]

91. Bai, Y.; Sun, Q.; Zhao, C.; Wen, D.; Tang, X. Aerobic degradation of pyridine by a new bacterial strain, Shinella zoogloeoides BC026. J. Ind. Microbiol. Biotechnol. 2009, 36, 1391-1400. [CrossRef] [PubMed]

92. Camargo, F.A.O.; Bento, F.M.; Okeke, B.C.; Frankenberger, W.T. Hexavalent chromium reduction by an actinomycete, Arthrobacter crystallopoietes ES 32. Biol. Trace Elem. Res. 2003, 97, 183-194. [CrossRef]

93. Van Horn, C.; Somera, T.; Mazzola, M. Comparative analysis of the rhizosphere and endophytic microbiomes across apple rootstock genotypes in replant orchard soils. Phytobiomes J. 2021. [CrossRef]

94. Lanfranco, L.; Bonfante, P.; Genre, A. The mutualistic interaction between plants and arbuscular mycorrhizal fungi. Microbiol. Spectrum 2016, 4. [CrossRef]

95. Fung, R.W.M.; Gonzalo, M.; Fekete, C.; Kovacs, L.G.; He, Y.; Marsh, E.; McIntyre, L.M.; Schachtman, D.P.; Qiu, W. Powdery Mildew Induces Defense-Oriented Reprogramming of the Transcriptome in a Susceptible but not in a Resistant Grapevine. Plant Physiol. 2008, 146, 236-249. [CrossRef] [PubMed] 